\title{
North Atlantic Oscillation and tropospheric ozone variability in Europe: model analysis and measurements intercomparison
}

\author{
F. S. R. Pausata ${ }^{1}$, L. Pozzoli ${ }^{2,1}$, E. Vignati ${ }^{1}$, and F. J. Dentener ${ }^{1}$ \\ ${ }^{1}$ European Commission, Joint Research Center, Institute for Environment and Sustainability, Ispra (VA), Italy \\ ${ }^{2}$ Eurasia Institute of Earth Sciences, Istanbul Technical University, Istanbul, Turkey
}

Correspondence to: F. S. R. Pausata (francesco.pausata@bjerknes.uib.no )

Received: 13 December 2011 - Published in Atmos. Chem. Phys. Discuss.: 30 January 2012

Revised: 8 June 2012 - Accepted: 2 July 2012 - Published: 23 July 2012

\begin{abstract}
Ozone pollution represents a serious health and environmental problem. While ozone pollution is mostly produced by photochemistry in summer, elevated ozone concentrations can also be influenced by long range transport driven by the atmospheric circulation and stratospheric ozone intrusions. We analyze the role of large scale atmospheric circulation variability in the North Atlantic basin in determining surface ozone concentrations over Europe. Here, we show, using ground station measurements and a coupled atmospherechemistry model simulation for the period 1980-2005, that the North Atlantic Oscillation (NAO) does affect surface ozone concentrations - on a monthly timescale, over $10 \mathrm{ppbv}$ in southwestern, central and northern Europe - during all seasons except fall. The commonly used NAO index is able to capture the link existing between atmospheric dynamics and surface ozone concentrations in winter and spring but it fails in summer. We find that the first Principal Component, computed from the time variation of the sea level pressure (SLP) field, detects the atmosphere circulation/ozone relationship not only in winter and spring but also during summer, when the atmospheric circulation weakens and regional photochemical processes peak. Given the NAO forecasting skill at intraseasonal time scale, the first Principal Component of the SLP field could be used as an indicator to identify areas more exposed to forthcoming ozone pollution events. Finally, our results suggest that the increasing baseline ozone in western and northern Europe during the 1990s could be related to the prevailing positive phase of the NAO in that period.
\end{abstract}

\section{Introduction}

High ozone $\left(\mathrm{O}_{3}\right)$ concentrations at the surface can have severe impact on human health and vegetation. In many modern cities and surrounding areas, ozone concentrations are often above thresholds for plant damage and negative health effects especially during late spring and summer (e.g. Akimoto, 2003; Lövblad et al., 2004; Dentener et al., 2006; EEA report, 2010). Elevated $\mathrm{O}_{3}$ concentrations are local-toregional phenomena, mainly associated with photochemical reactions favored by a combination of intense solar radiation and emissions of air pollutants. However, in the last twenty years, several studies have shown that tropospheric ozone can be transported over long distances, affecting $\mathrm{O}_{3}$ concentrations at the surface (e.g. Parrish et al., 1993; Fehsenfeld et al., 1996; Yienger et al., 2000; Wild and Akimoto, 2001; Li et al., 2002; Creilson et al., 2003; Brown-Steiner and Hess, 2011). This long range $\mathrm{O}_{3}$ transport mainly occurs during perturbed weather conditions, which, however, are generally not associated with highest surface $\mathrm{O}_{3}$ concentrations during summer (Guerova et al., 2006). Nevertheless, long range transport of $\mathrm{O}_{3}$ and its precursors across the Atlantic basin does affect the mean surface $\mathrm{O}_{3}$ concentrations over Europe (e.g. Bronnimann et al., 2000, 2002; Simmonds et al., 2004).

Another source for surface $\mathrm{O}_{3}$ is associated with transport of stratospheric air into the troposphere (STT). Various dynamic mechanisms are responsible for transport of $\mathrm{O}_{3}$ enriched stratospheric air into the troposphere (Stohl et al., 2003), such as tropospause folds, cut-off lows, convective overshoots. While it is often difficult to attribute surface ozone to specific STT events, STT is important for estimating ozone budget climatology and long term baseline trends

Published by Copernicus Publications on behalf of the European Geosciences Union. 
of surface ozone, due to continuous chemical $\mathrm{O}_{3}$ cycling entering the troposphere from the stratosphere (Lelieveld and Dentener, 2000; Hocking et al., 2007; Lin et al., 2012).

Regional scale processes, long range transport across the Atlantic Ocean and STT events over Europe are influenced by the North Atlantic Oscillation (NAO). The simplest NAO definition is "the tendency for pressure to be low near Iceland in winter when it is high near the Azores" and vice versa (Walker and Bliss, 1932). The NAO refers to swings in the atmospheric pressure difference between these two centers of action and dictates climate variability from the eastern seaboard of the United States to Siberia and from the Arctic to the subtropical Atlantic. Therefore, the NAO plays an important role in determining intercontinental transport of air masses as well as affecting regional scale atmospheric processes.

A common measure of the NAO phase is the so-called NAO index (NAOI) that is determined by the strength and the location of the semi-permanent Icelandic low and Azores high pressure systems (Walker, 1924; Walker and Bliss, 1932). The NAOI is commonly defined as the difference in the normalized sea level pressure (SLP) anomalies between either Lisbon, Portugal, or Ponte Delgada, Azores, and Stykkisholmur/Reykjavik, Iceland (Hurrell, 1995). In winter, during positive NAO phases the Icelandic low deepens and the Azores high strengthens increasing the SLP gradient and consequently enhancing the westerly flow as well as intercontinental transport of air masses. This leads to abovenormal precipitation and milder temperature over northern Europe, and drier weather conditions in the Mediterranean area. The negative phase of the NAO is associated with a slackening of the westerlies and enhanced meridional $(\mathrm{N}-$ S) atmospheric mass exchange. The weather related to low NAO phases is characterized by drier conditions in northern Europe and above-normal precipitation in southern Europe.

The NAO is often regarded as a winter phenomenon, since winter months are dynamically the most active and present the largest SLP amplitude anomalies. However, Barnston and Livezey (1987) showed that the NAO has a year-round influence on weather conditions in Europe with pronounced seasonal variation in location of the high and low pressure centers, and strong climate anomalies can also be detected outside the winter season. This is particularly important for summer, when atmospheric variability influenced by the NAO can lead to severe droughts and heat waves as well as prolonged photochemical smog (Linderholm et al., 2009; Bladé et al., 2011). However, the NAOI as defined above is not able to accurately capture this variability in summer, since stationbased indices are fixed in space and therefore cannot account for the seasonal migration of the NAO centers of actions. An alternative definition of NAOI is based on the empirical orthogonal function (EOF) analysis of the SLP field: the NAOI can be identified as the leading eigenvector (the first Principal Component, PC1) computed from the time variation of the SLP field (Hurrell, 1995; Hurrell et al., 2003; Wallace,
2000). The associated PC1 is used to evaluate the temporal evolution of the NAO in any season. The spatial pattern representing the NAO is given by the leading EOF (EOF1). The advantage of using EOF analysis of the SLP field is that the $\mathrm{PC} 1$ index provides a more accurate representation of the NAO pattern taking into account the shifting of the NAO centers of action throughout the year.

Li et al. (2002), using a 5-yr simulation performed with a three dimensional global chemistry model, found that North American influence on surface $\mathrm{O}_{3}$ at Mace Head (Ireland) is strongly correlated with the NAO, especially in spring. Creilson et al. (2003) have described the link between the NAO and the seasonal and regional distribution of tropospheric ozone calculated using the tropospheric ozone residual technique. They have found a strong correlation between NAO and tropospheric $\mathrm{O}_{3}$ over western Europe in spring. Other studies have investigated the long range transport of pollutants and $\mathrm{O}_{3}$ precursors across the Atlantic into Europe associated with the NAO, using a chemistry-transport model (Duncan and Bey, 2004) and into the Arctic using passive tracers (Eckhardt et al., 2003). Sprenger and Wernli (2003) have shown that the NAO, affecting the synoptic-scale and meso-scale processes (cut-off lows and jets positions), also influences the STT of $\mathrm{O}_{3}$ enriched air.

Most studies have used the station-based NAOI (e.g. Li et al., 2002; Creilson et al., 2003) to evaluate the behavior of long range transport of $\mathrm{O}_{3}$ or other pollutants across the Atlantic Ocean, showing a weak - if any - correlation in the summer months. On the other hand, few studies have used the EOF-based index (PC1) to investigate intercontinental transport of gases and pollutants or ozone variability. Using the ECHAM/MESSy atmospheric chemistry model with idealized water insoluble and soluble tracers, Christoudias et al. (2012) have investigated the influence of the NAO on the atmospheric dispersion of pollution, focusing only in winter when NAOI and PC1 are actually strongly correlated (e.g. Wallace, 2000). Hess and Lamarque (2007) have used a chemistry transport model to analyze tropospheric ozone variability in February and March in the period 1980-2001 associated with the Arctic Oscillation. The Arctic Oscillation and the NAO are highly correlated, however, the Arctic Oscillation also includes the dominant mode of variability of the North Pacific (the North Pacific Oscillation). Therefore, when focusing exclusively over the Atlantic basin the NAO is more appropriate (e.g. Hurrell, 1995; Hurrell et al., 2003).

The objective of this study is extending the previous works on the relationship of NAO and ozone to all seasons, including the high ozone season. This is of particular importance, since some climate model predictions have shown a trend towards more frequent positive NAO phases in the coming decades (Fyfe et al., 1999; Gillett et al., 2001; Kuzmina et al., 2005; Stephenson et al., 2006). Therefore it is of high relevance to clearly understand the link between the NAO and $\mathrm{O}_{3}$ concentrations throughout the year, but especially in summer when surface $\mathrm{O}_{3}$ concentrations build up on top of baseline 
Table 1. Ground stations with geographical coordinates and years used in the analysis.

\begin{tabular}{lcccc}
\hline Station & Latitude & Longitude & Altitude (a.s.l.) & Years \\
\hline Viznar (Spain) & $37^{\circ} 14^{\prime} 00^{\prime \prime} \mathrm{N}$ & $03^{\circ} 32^{\prime} 00^{\prime \prime} \mathrm{W}$ & $1265 \mathrm{~m}$ & $1995-2005$ \\
Monte Velho (Portugal) & $38^{\circ} 05^{\prime} 00^{\prime \prime} \mathrm{N}$ & $08^{\circ} 48^{\prime} 00^{\prime \prime} \mathrm{W}$ & $43 \mathrm{~m}$ & $1990-2005$ \\
Montelibretti (Italy) & $42^{\circ} 06^{\prime} 00^{\prime \prime} \mathrm{N}$ & $12^{\circ} 38^{\prime} 00^{\prime \prime} \mathrm{E}$ & $48 \mathrm{~m}$ & $1995-2005$ \\
Illmitz (Austria) & $47^{\circ} 46^{\prime} 00^{\prime \prime} \mathrm{N}$ & $16^{\circ} 46^{\prime} 00^{\prime \prime} \mathrm{E}$ & $117 \mathrm{~m}$ & $1990-2005$ \\
Donon (France) & $48^{\circ} 30^{\prime} 00^{\prime \prime} \mathrm{N}$ & $07^{\circ} 08^{\prime} 00^{\prime \prime} \mathrm{E}$ & $775 \mathrm{~m}$ & $1995-2005$ \\
Eupen (Belgium) & $50^{\circ} 37^{\prime} 46^{\prime \prime} \mathrm{N}$ & $06^{\circ} 00^{\prime} 10^{\prime \prime} \mathrm{E}$ & $295 \mathrm{~m}$ & $1990-2005$ \\
Yarner Wood (England) & $50^{\circ} 35^{\prime} 47^{\prime \prime} \mathrm{N}$ & $03^{\circ} 42^{\prime} 47^{\prime \prime} \mathrm{W}$ & $119 \mathrm{~m}$ & $1990-2005$ \\
Mace Head (Ireland) & $53^{\circ} 10^{\prime} 00^{\prime \prime} \mathrm{N}$ & $09^{\circ} 30^{\prime} 00^{\prime \prime} \mathrm{W}$ & $15 \mathrm{~m}$ & $1990-2005$ \\
Lough Navar (North. Ireland) & $54^{\circ} 26^{\prime} 35^{\prime \prime} \mathrm{N}$ & $07^{\circ} 12^{\prime} 52^{\prime \prime} \mathrm{W}$ & $126 \mathrm{~m}$ & $1990-2005$ \\
Sniezka (Poland) & $50^{\circ} 44^{\prime} 00^{\prime \prime} \mathrm{N}$ & $15^{\circ} 44^{\prime} 00^{\prime \prime} \mathrm{E}$ & $1603 \mathrm{~m}$ & $1995-2005$ \\
Leba (Poland) & $54^{\circ} 45^{\prime} 00^{\prime \prime} \mathrm{N}$ & $17^{\circ} 32^{\prime} 00^{\prime \prime} \mathrm{E}$ & $2 \mathrm{~m}$ & $1995-2005$ \\
Langenbrugge (Germany) & $52^{\circ} 48^{\prime} 08^{\prime \prime} \mathrm{N}$ & $10^{\circ} 45^{\prime} 34^{\prime \prime} \mathrm{E}$ & $74 \mathrm{~m}$ & $1990-2005$ \\
Neuglobsow (Germany) & $53^{\circ} 10^{\prime} 00^{\prime \prime} \mathrm{N}$ & $13^{\circ} 02^{\prime} 00^{\prime \prime} \mathrm{E}$ & $62 \mathrm{~m}$ & $1991-2005$ \\
Westerland (Germany) & $54^{\circ} 55^{\prime} 32^{\prime \prime} \mathrm{N}$ & $08^{\circ} 18^{\prime} 35^{\prime \prime} \mathrm{E}$ & $12 \mathrm{~m}$ & $1990-2005$ \\
Rørwik (Sweden) & $57^{\circ} 25^{\prime} 00^{\prime \prime} \mathrm{N}$ & $11^{\circ} 56^{\prime} 00^{\prime \prime} \mathrm{E}$ & $10 \mathrm{~m}$ & $1990-2002$ \\
Råö (Sweden) & $57^{\circ} 23^{\prime} 38^{\prime \prime} \mathrm{N}$ & $11^{\circ} 54^{\prime} 50^{\prime \prime} \mathrm{E}$ & $5 \mathrm{~m}$ & $2003-2005$ \\
Birkenes (Norway) & $58^{\circ} 23^{\prime} 00^{\prime \prime} \mathrm{N}$ & $08^{\circ} 15^{\prime} 00^{\prime \prime} \mathrm{E}$ & $190 \mathrm{~m}$ & $1990-2005$ \\
\hline
\end{tabular}

$\mathrm{O}_{3}$ levels and can be dangerous for the environment and human health.

Here we compare the conventional station-based and the alternative EOF-based NAO definition in all seasons. We study the $\mathrm{NAO} / \mathrm{O}_{3}$ relationship using $\mathrm{O}_{3}$ concentrations from several ground stations spread over Europe and then we extend this analysis applying a coupled atmosphere-chemistry model in a hindcast setup for the years 1980-2005. The comparison between these two indices - using a 26 yr model simulation rather than few years as done in several previous studies (e.g. Li et al., 2002; Duncan and Bey, 2004) - provides a more robust overview of the relationship between $\mathrm{O}_{3}$ variability and atmospheric dynamics. It also allows us to understand whether taking into account the latitudinal shifting in the atmospheric circulation mean flow throughout the year can improve our ability to detect correlations between atmospheric dynamics and $\mathrm{O}_{3}$ concentrations. Furthermore, we analyzed $\mathrm{O}_{3}$ anomalies through the depth of the troposphere associated with the two NAO phases in order to infer potential stratospheric influence onto surface $\mathrm{O}_{3}$ concentrations.

In Sect. 2 we describe the data and the model used in this study. We present the $\mathrm{NAO} / \mathrm{O}_{3}$ relationship and $\mathrm{O}_{3}$ concentrations anomalies associated with the NAO phases in Sect. 3. We discuss the implications of our findings in Sect. 4. Conclusions are presented in Sect. 5.

\section{Data and methods}

In this study we selected a total of 17 stations from the 150 stations belonging to the European Monitoring and Evaluation Programme (EMEP, http://www.emep.int/) for which monthly mean $\mathrm{O}_{3}$ concentrations are available between 1990 and 2005 (Table 1). We have chosen a subset of relatively unpolluted stations with sufficiently long timeseries in order to have a representative coverage of the areas most influenced by the NAO. We have considered only the monthly $\mathrm{O}_{3}$ anomalies, removing the monthly annual mean from each stations. Given the proximity of the two Swedish stations (Rørwik and Råö, $3 \mathrm{~km}$ ) and the years available (19902002 and 2003-2005), we have merged their monthly $\mathrm{O}_{3}$ anomalies timeseries.

In addition to the measurement data analysis, we have extended our study using the model results from the reanalysis simulation of Pozzoli et al. (2011). The chemical composition of the troposphere was simulated for the period 1980-2005 with the fully coupled aerosol-chemistry climate model, ECHAM5-HAMMOZ, described in detail in Pozzoli et al. (2008a). The model is composed of the general circulation model ECHAM5 (Roeckner et al., 2003, 2006; Hagemann et al., 2006), the tropospheric chemistry module MOZ (MOZART-2, Horowitz et al., 2003), and the aerosol module HAM (Stier et al., 2005). The meteorological fields and chemical composition of the troposphere are available at the horizontal resolution of about $2.8^{\circ} \times 2.8^{\circ}$, and with 31 vertical levels from the surface up to $10 \mathrm{hPa}$. The meteorology (vorticity, divergence, sea surface temperature and surface pressure) was nudged (Jeuken et al., 1996) with the ECMWF ERA-40 re-analysis (Uppala et al., 2005) until 2000 and by operational analyses (IFS cycle-32r2) for the remaining period (2001-2005). We must note that this discontinuity may have an impact on the meteorological variables; however, Pozzoli et al. (2011) did not find any evidence for this. The nudging technique forces the large scale dynamic state of the atmosphere towards the re-analysis data, thus the model is in a consistent physical state with the reanalysis at each time 
step but it calculates its own physics (e.g. for aerosol and clouds).

We used one of the two transient simulations performed in Pozzoli et al. (2011) (their SREF simulation), in which anthropogenic emissions are changing on an hourly-to-monthly basis in order to be as close as possible to the observations. Natural emissions and emission of $\mathrm{O}_{3}$ precursors were calculated on-line by ECHAM5-HAMMOZ considering the meteorological variability. A detailed description of the emission inventories used can be found in Pozzoli et al. (2011).

Stratospheric $\mathrm{O}_{3}$ concentrations are prescribed as monthly mean zonal climatology derived from observations (Randel et al., 1998; Logan, 1999). The $\mathrm{O}_{3}$ concentrations are fixed at the topmost two model levels (pressures of 30 and $10 \mathrm{hPa}$ ). Between the tropopause and $30 \mathrm{hPa}$, the concentrations are relaxed towards the climatology values with a relaxation time of 10 days (Pozzoli et al., 2011).

The ECHAM5-HAMMOZ model has been extensively evaluated in previous studies (Stier et al., 2005; Pozzoli et al., 2008a,b, 2011; Auvray et al., 2007; Rast et al., 2012) with comparisons to several measurements and within model intercomparison studies. We must point out a substantial overestimate of our computed ozone compared to measurements by up to $15 \mathrm{ppbv}$ in some regions, especially over the Mediterranean area (Rast et al., 2012). Rast et al. (2012) suggest that the high bias observed may be a consequence of advection of ozone-rich air from aloft and trapping of polluted air masses in the boundary layer. Over the rest of Europe the biases are lower with best agreements exhibited in Eastern Europe. Overestimation of surface ozone is a yearround problem that ECHAM5-HAMMOZ shares with many other global models (Ellingsen et al., 2008). Nevertheless, the model captures the observed range of interannual $\mathrm{O}_{3}$ variability. Pozzoli et al. (2011) analyzed seasonally averaged modeled and measured surface ozone concentrations and found a reasonably good agreement for a large number of North American and European stations. The tropospheric $\mathrm{O}_{3}$ burden (Stevenson et al., 2006) and variability (Hess and Mahowald, 2009) agree well with earlier studies.

The model data analyzed here are restricted to the Atlantic sector $\left(20^{\circ}-90^{\circ} \mathrm{N}, 90^{\circ} \mathrm{W}-40^{\circ} \mathrm{E}\right)$ and the results are based on monthly anomalies from the climatological monthly mean. Standard Empirical Orthogonal Function (EOF)/Principal Component (PC) analysis has been used to calculate the leading mode of monthly SLP variability in the North Atlantic. The NAOI timeseries have been calculated as the difference in the normalized SLP anomalies between the model grid boxes corresponding to the location of Ponte Delgada, Azores and Stykkisholmur/Reykjavik, Iceland. The PC1 timeseries for each season has been normalized dividing it by its standard deviation. Hereafter we refer to NAO as the general term for the latitudinal shifting of air mass in all seasons not necessary linked to the station-based or PC1based index (i.e. $\mathrm{NAO}=\mathrm{EOF} 1$ ), whereas we clearly distinguish when we are referring to the PC1 or NAOI timeseries.
The correlation between $\mathrm{O}_{3}$ anomalies and NAOI/PC1 timeseries are calculated using the Pearson's linear correlation coefficient and all significant correlations discussed in the text refer to the 0.1 significance level ( $90 \%$ confidence interval).

\section{Results}

The results presented here describe the correlations between the atmospheric variability and $\mathrm{O}_{3}$ concentrations seen by ground station measurements and the atmosphere model. The results are presented in three sections. In the first section, we present the simulated climatological (1980-2005) SLP field and its variability, and tropospheric and surface $\mathrm{O}_{3}$ mean state for each season. In the second section, we first discuss the general relationship between the NAOI/PC1 and the $\mathrm{O}_{3}$ concentrations as measured by ground stations, and then we extend our analysis to the modeled NAOI/PC1 and $\mathrm{O}_{3}$ relationship and the associated surface $\mathrm{O}_{3}$ anomalies. In the third section, we investigate $\mathrm{O}_{3}$ anomalies through the depth of the troposphere, as represented by the model.

\subsection{Simulated climatological (1980-2005) SLP and $O_{3}$ mean}

\subsubsection{SLP climatology}

The simulated SLP climatology, interannual variability and the NAO faithfully reproduce observations (http://www.cgd. ucar.edu/cas/jhurrell/indices.info.html\#naostatann), given that the simulated meteorology fields are relaxed towards the ERA-40 reanalyzed data. As a consequence the modeled monthly NAOI is in very good agreement with the observed NAOI $(R=0.94)$. In the North Atlantic, the year-round SLP pattern is characterized by two main centers of action: a low and a high pressure systems situated in the proximity of Iceland and Azores respectively (Fig. 1), which determine the phase of the NAO - the dominant mode of atmospheric circulation in the Atlantic sector.

The EOF analysis of the monthly SLP field shows that in winter, the NAO controls a significant fraction of the SLP variability in the North Atlantic, accounting for more than $40 \%$ of its total variance (Fig. 1). The SLP variability is also associated with pronounced atmospheric pressure swings between the positive and the negative phase of the NAO. Going towards summer, the amplitude of SLP swings and explained variability decreases reaching a minimum in summer (SLP swings are more than halved compared to winter) and fall $(28 \%)$ respectively. Considering the percentage of SLP variance explained in the different seasons, the maximum influence of the $\mathrm{NAO}$ on $\mathrm{O}_{3}$ concentration is expected to be in winter, whereas the minimum is expected in fall. The NAOI and PC1 monthly timeseries are strongly correlated in winter $(r=0.86)$ when the atmospheric circulation is well described by the NAOI; whereas in summer, the correlation reaches the minimum $(r=0.59)$, given the northward shift of 

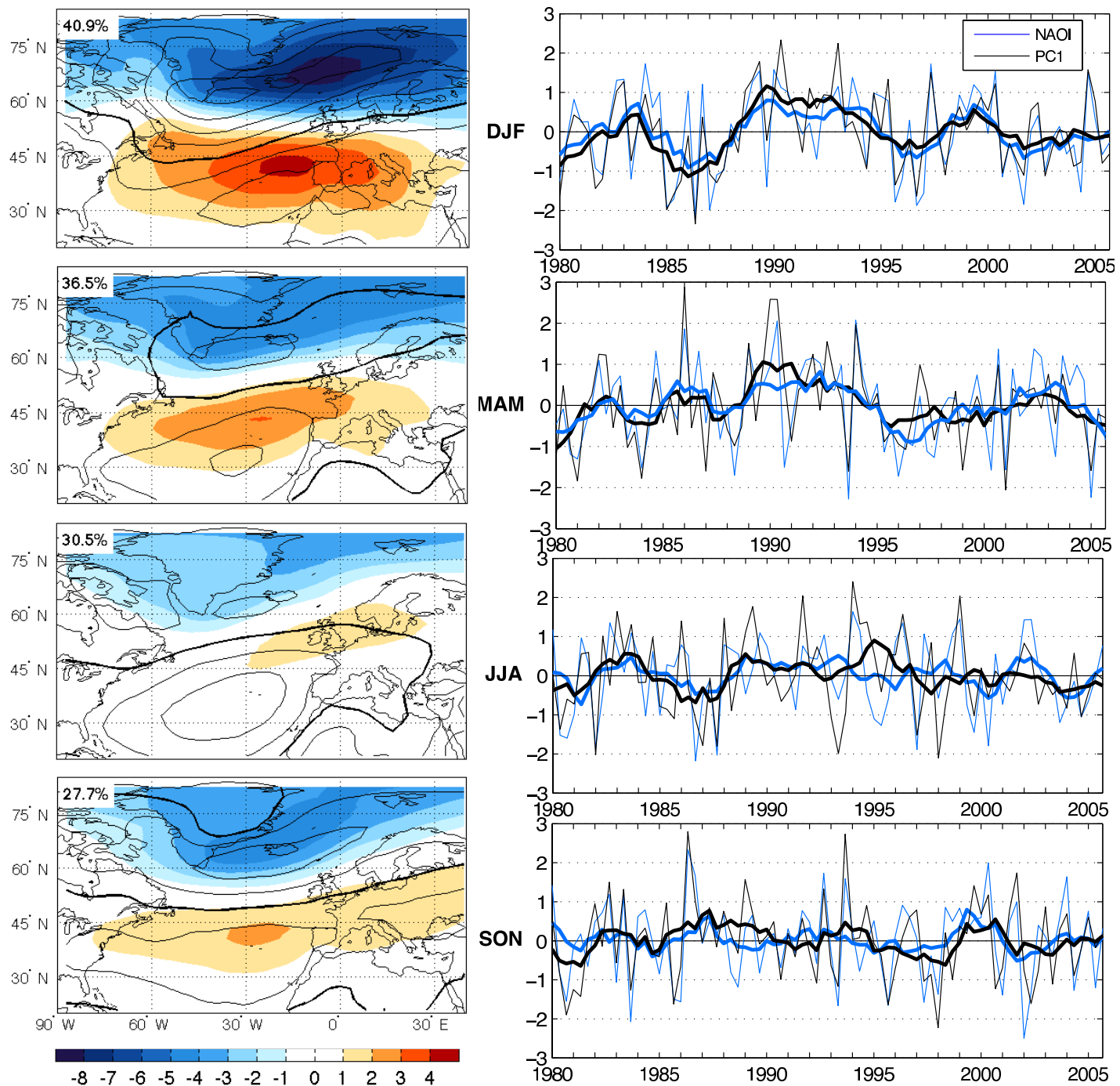

Fig. 1. Left panels: Simulated leading EOF of monthly SLP anomalies (colored shading: $h \mathrm{~Pa} / \mathrm{standard}$ deviation of PC) using data from all months of each season and SLP mean (contours: $4 \mathrm{hPa}$ interval from 998 to $1022 \mathrm{hPa}$; bold contour denotes $1014 \mathrm{hPa}$ ) in the North Atlantic sector. The EOF patterns represent the SLP anomalies associated with normalized PC1 equal to 1 for the NAO positive phase (opposite sign for the NAO negative phase). Bold numbers in the upper left corners show the amount of variance explained by the first EOF as a percentage of the total variance for each season. Right panels: NAOI (blue) and normalized PC1 (black) timeseries for each season. The bold lines show the 6-month (2 seasons) running mean.

the low and high pressure systems. In the transition seasons the PC1/NAOI correlation is around 0.75 .

In the analyzed period (1980-2005), the PC1 timeseries shows a persistent NAO positive phase from 1988 till 1996 in all seasons, except in fall when no dominating phase is found (Fig. 1). This persistent NAO positive phase is particularly evident in winter when from 1988 to 2000 only the period 1996-1998 have shown a weak negative NAO phase.

\subsubsection{Tropospheric ozone mean climatology}

In this section we compare model calculated tropospheric ozone average with satellite determined ozone, to verify the large-scale consistency of spatial and temporal patterns. To this end we use the tropospheric $\mathrm{O}_{3}$ column inferred by using the Tropospheric Ozone Residual (TOR) technique (Fig. 3). The TOR technique uses measurements from the Total Ozone Mapping Spectrometer and Solar Back scattered Ultraviolet instruments and it is described in details in Fishman et al., 2003. Both the TOR values and the tropospheric $\mathrm{O}_{3}$ burden in this study have being derived up to the thermal tropopause, defined as the lowest level at which the lapse rate does not exceed $2 \mathrm{~K} \mathrm{~km}^{-1}$ and remains lower than $2 \mathrm{~K} \mathrm{~km}^{-1}$ for the following $2 \mathrm{~km}$. Like surface ozone (Sect. 2), also the modeled tropospheric $\mathrm{O}_{3}$ burden exhibits an overestimation compared to the satellite observations (Fig. 3). 

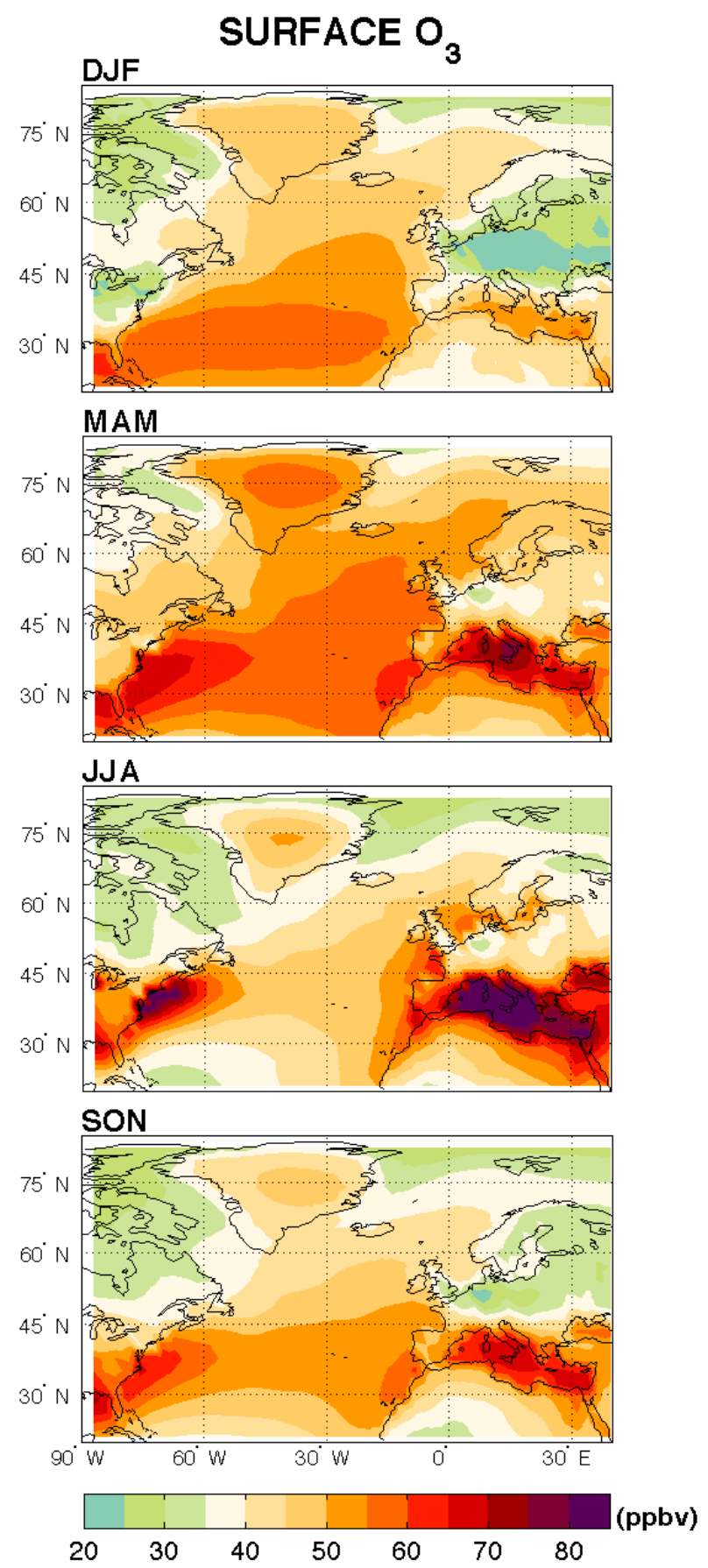

Fig. 2. Seasonal climatology (1980-2005) of modeled surface $\mathrm{O}_{3}$ volume mixing ratios.

The simulated surface (Fig. 2) and tropospheric $\mathrm{O}_{3}$ column (Fig. 3) shows a distinct seasonal cycle that peaks mostly in late spring/early summer and reaches a minimum in winter. The spatial distribution of the simulated tropospheric $\mathrm{O}_{3}$ column shows a remarkably similar behavior to the TOR values (Fig. 3). Among factors contributing to the discrepancies in the pattern, there could be the lower resolution of the climate model $\left(\sim 3 \times 3^{\circ}\right)$ compared to the TOR grid $\left(\sim 1 \times 1^{\circ}\right)$.

As mentioned in Sect. 2, for the scope of this paper the overestimation of the $\mathrm{O}_{3}$ values is not critical to the study, since the focus of this study is on patterns of spatial and temporal variability of surface $\mathrm{O}_{3}$.

\subsection{NAO and surface $\mathrm{O}_{3}$}

\subsubsection{Measured surface $\mathrm{O}_{3}$ and NAO correlation}

During winter (December to February, DJF), the NAO impact on surface $\mathrm{O}_{3}$ concentrations is remarkable: up to 8 out of 16 stations show a significant positive correlation between $\mathrm{NAOI} / \mathrm{PC} 1$ and $\mathrm{O}_{3}$ (with maximum $R=0.62$ for the $\mathrm{NAOI} / \mathrm{O}_{3}$ correlation at Mace Head, see also Fig. 4). The stations with significant positive correlations extend from Ireland to southern Norway and Sweden, to Central Europe. On the other hand, in fall (September to November, SON) NAO and $\mathrm{O}_{3}$ concentrations show the weakest correlation where only 2 to 4 stations have significant positive correlations.

In spring (March to May, MAM), $\mathrm{O}_{3}$ concentrations in Ireland remain significantly positively correlated with the $\mathrm{NAO}\left(\mathrm{NAOI} / \mathrm{O}_{3}\right.$ around $\left.0.30 / 0.40\right)$ whereas at most stations in northern and central Europe the correlation weakens and become negative (mostly not significant). Weak negative correlations also appear in Portugal.

The summer season (June to August, JJA) displays the greatest difference between the $\mathrm{NAOI} / \mathrm{O}_{3}$ and the $\mathrm{PC} 1 / \mathrm{O}_{3}$ correlations. The $\mathrm{NAOI} / \mathrm{O}_{3}$ correlation turns out to be significant only in two stations located in southern Sweden (positive) and North Ireland (negative), whereas non-significant correlations are found in Central Europe (negative) in the Iberian peninsula (positive). The $\mathrm{PC} 1 / \mathrm{O}_{3}$ correlation exhibits instead an opposite sign in central Europe and Ireland, and presents more locations with significant correlations compared to the $\mathrm{NAOI} / \mathrm{O}_{3}$ correlation. Significant positive $\mathrm{PC} 1 / \mathrm{O}_{3}$ correlations $(0.30 / 0.35)$ are found over the Iberian peninsula, Ireland, northern Germany and southern Scandinavia, whereas no negative correlations are found (Fig. 4).

\subsubsection{Modeled surface $\mathrm{O}_{3}$ and NAO correlation}

In order to further investigate the correlation between NAO and surface $\mathrm{O}_{3}$, we turn to the model simulation that allows to better understand the correlation pattern over the whole Atlantic sector. To quantify the effects of the NAO onto surface $\mathrm{O}_{3}$ concentrations, we also analyze surface ozone anomalies associated with ensemble averages of high and low NAO phase winter and summer months. The ensemble averages are calculated considering $\mathrm{O}_{3}$ concentration anomalies for each winter and summer month with normalized PC1 anomalies greater than 1 in absolute value (Table 2). While we have considered $\mathrm{NAO}$ and surface $\mathrm{O}_{3}$ for all seasons, we have analyzed surface $\mathrm{O}_{3}$ anomalies only in winter and summer, since 

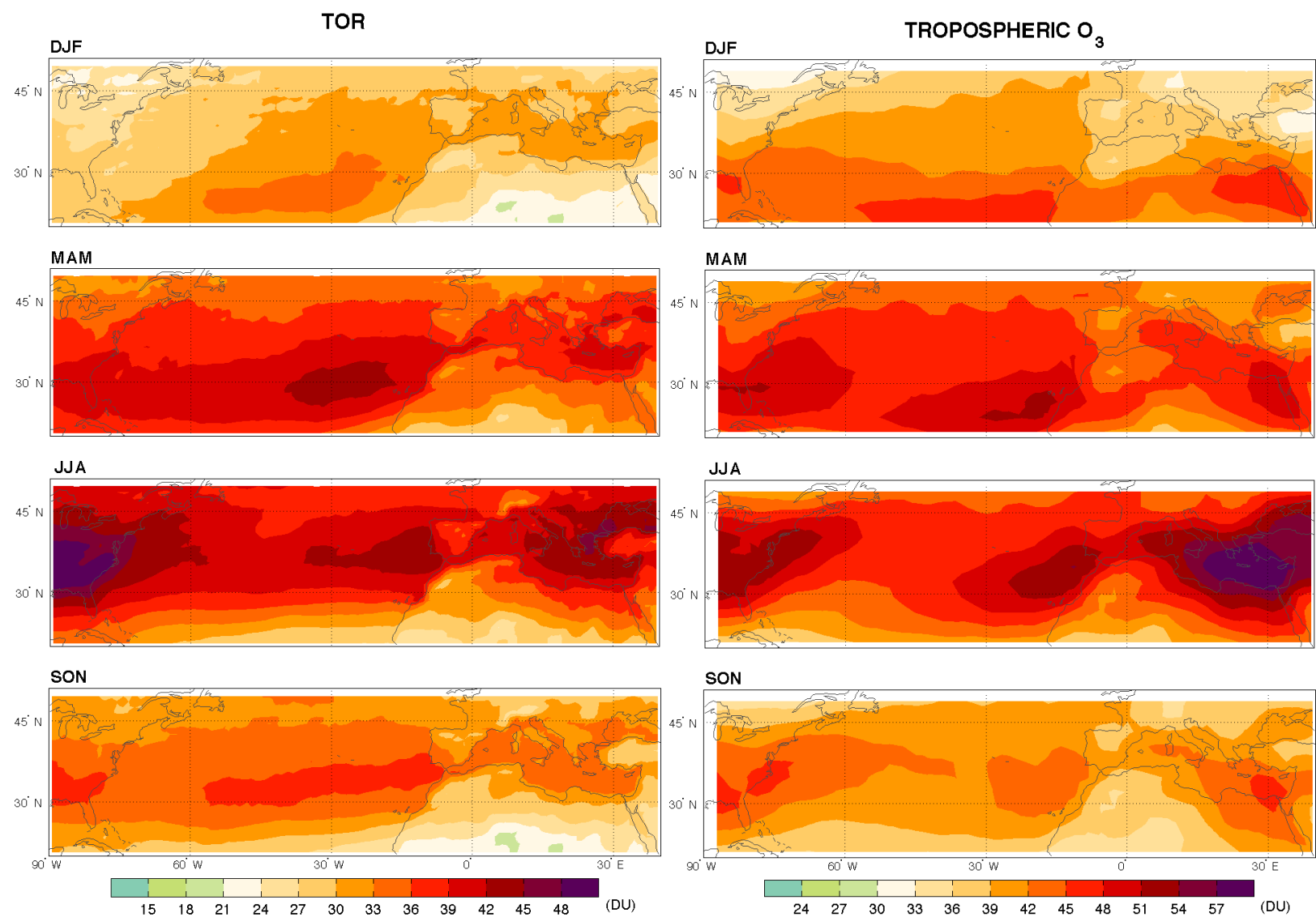

Fig. 3. Climatological (1980-2005) tropospheric ozone residual (left) and modeled tropospheric $\mathrm{O}_{3}$ burden (right) in the North Atlantic for each season. Note the use of different colorscales to emphasize pattern similarities.

they are the two extreme seasons: in winter, the limited photochemical production of ozone, leads to a larger role played by the atmospheric dynamics in determining the $\mathrm{O}_{3}$ variability, and in summer both dynamical and photochemical processes come into play, leading to elevated $\mathrm{O}_{3}$ concentrations.

Like the measurements, the model simulation shows the strongest significant correlations between $\mathrm{O}_{3}$ concentrations and NAO in winter and the weakest correlations in fall over Europe (Fig. 5).

\section{Winter}

The strong winter (DJF) influence of the NAO on surface $\mathrm{O}_{3}$ concentrations is mainly driven by large-scale atmospheric circulation and is less strongly affected by $\mathrm{O}_{3}$ photochemical reactions. As expected, the NAOI and the PC1 timeseries show a similar, though not identical, correlation pattern with simulated surface $\mathrm{O}_{3}$ concentrations. The significant positive correlations displayed over the British Isles, Central Europe and southern Scandinavia match the correlation pattern obtained using the ground-station $\mathrm{O}_{3}$ measurements (cf. Figs. 4 and 5). The $\mathrm{O}_{3}$ anomaly pattern associated to the NAO in
Fig. 6 is remarkably similar to the February-March pattern shown by Hess and Lamarque (2007) (their Fig. 4). The positive surface $\mathrm{O}_{3}$ anomalies of up to $10 \mathrm{ppbv}$ displayed over the British Isles, Central Europe and southern Scandinavia (Fig. 6) during positive NAO phases are most likely due to the transport of $\mathrm{O}_{3}$ enriched air masses from the Atlantic Ocean (Figs. 2 and 3). This long range low-level transport of enriched $\mathrm{O}_{3}$ air masses has also been shown by $\mathrm{Li}$ et al. (2002) for Mace Head using a model simulation with artificial tracers. In contrast, the transport of $\mathrm{O}_{3}$ from the Atlantic Ocean is reduced over the Iberian Peninsula due to the expansion of the Azores anticyclone. The expansion of the Azores high carries $\mathrm{O}_{3}$ depleted air masses southward from the European continent to the Italian peninsula and $\mathrm{O}_{3}$ enriched air from the Mediterranean Sea to Africa. This flow along the eastern flank of the anticyclone leads to lowerthan-normal surface $\mathrm{O}_{3}$ concentrations over most of Italy (as can also be inferred by the measurements) and higher-thannormal surface $\mathrm{O}_{3}$ concentrations over north-eastern Africa (Figs. 5 and 6). The strengthening of the trade winds induced by a more vigorous Azores anticyclone, enhances the transport of depleted $\mathrm{O}_{3}$ Saharan air masses towards the coast of western Africa. 

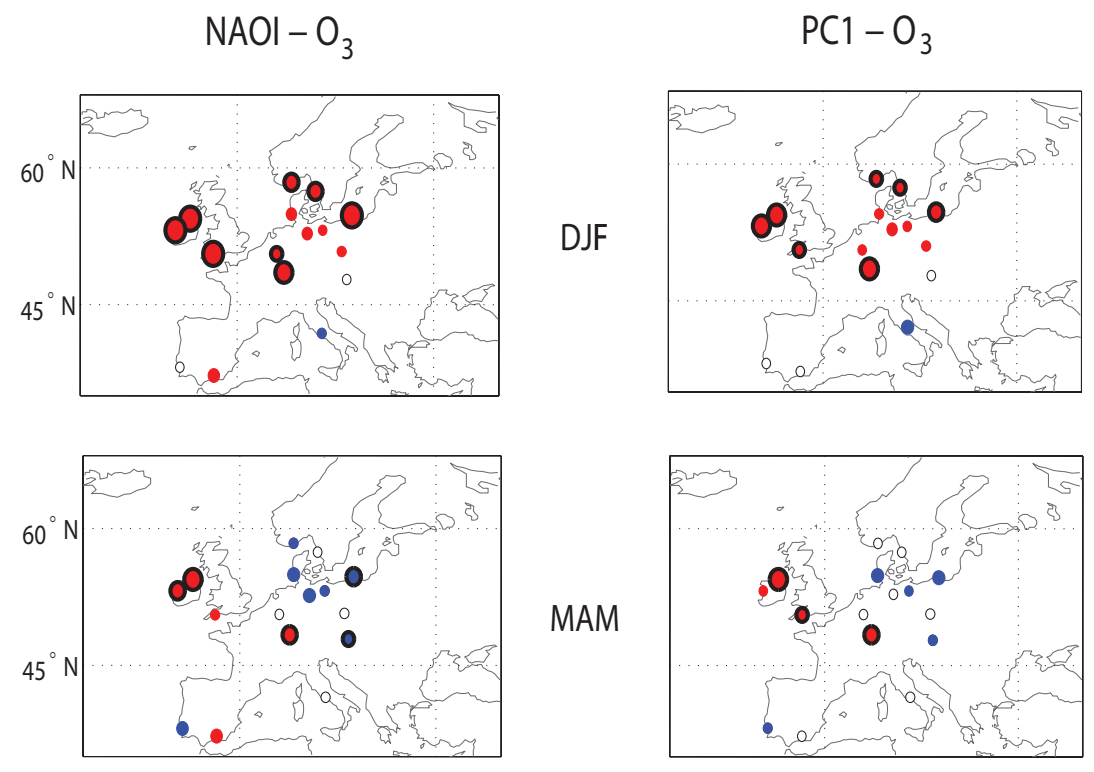

$R>0.5$

$0.4<R<0.5$

$0.3<R<0.4$

$0.2<\mathrm{R}<0.3$

- $0.1<\mathrm{R}<0.2$
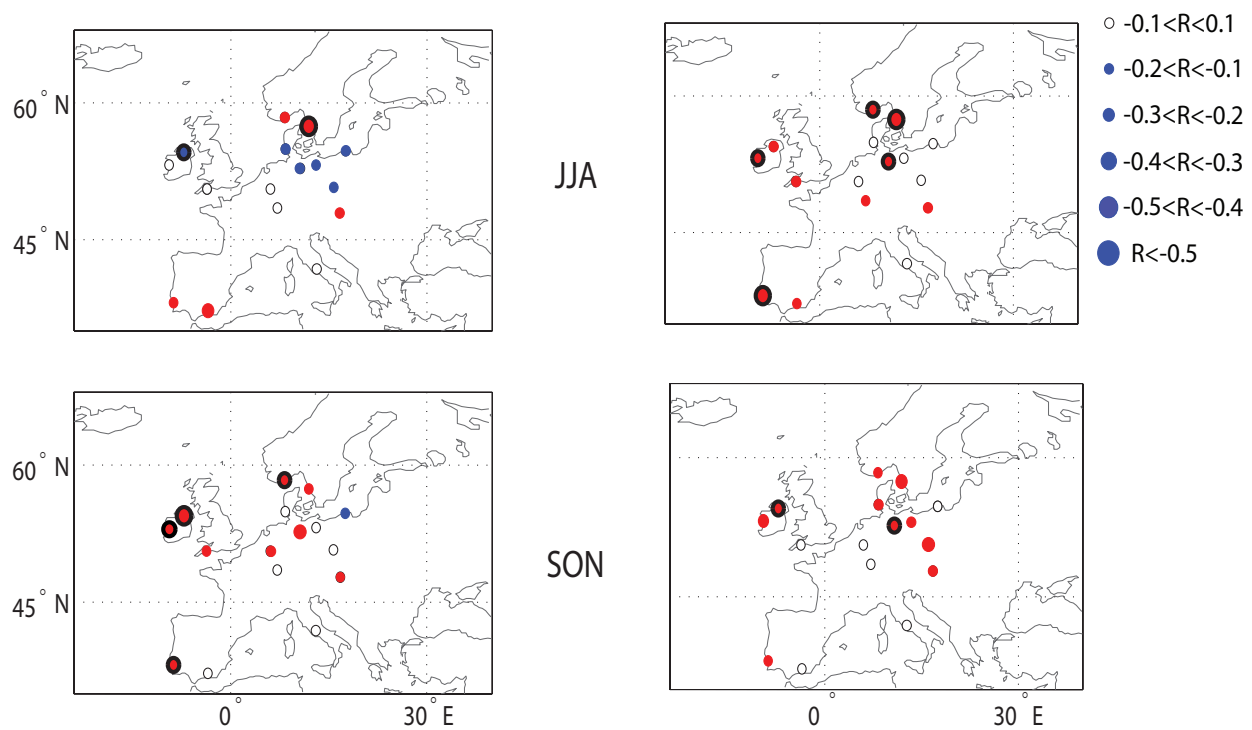

Fig. 4. Seasonal correlation calculated from monthly data between NAOI (left) and PC1 (right), and surface $\mathrm{O}_{3}$ volume mixing ratios measured at ground stations listed in Table 1. The correlation intervals are shown in the legend. Black bold rings indicate significant correlation with $90 \%$ confidence.

On the other hand, negative NAO phases are often associated with blocking events in the North Atlantic that reduce the contribution of $\mathrm{O}_{3}$ enriched air from the ocean and the $\mathrm{O}_{3}$ depleted flow from the European continent is more likely to make its way to the British Isles and western Europe. The negative phase of NAO leads to a southward shift towards the Mediterranean Sea of the storm tracks carrying $\mathrm{O}_{3}$ enriched air masses from the Atlantic Ocean, which leads to an increase by a few ppbv of surface $\mathrm{O}_{3}$ concentrations in the western part of the Iberian peninsula (Fig. 6). More storms in the Mediterranean Sea enhance the southerly flow towards Italy and northern Africa leading to slightly increased surface $\mathrm{O}_{3}$ concentrations over the Italian peninsula and decreased surface $\mathrm{O}_{3}$ values in north-eastern Africa. The weakening of the trade winds associated with the low NAO phase are not intense enough to lead to positive surface $\mathrm{O}_{3}$ anomalies over western Africa: the SLP anomalies for the negative NAO phase over the Sahara desert and western Africa are weaker in absolute values than the SLP anomalies associated with the positive NAO phase (Fig. 6).

\section{Spring}

In spring (MAM), the $\mathrm{PC} 1 / \mathrm{O}_{3}$ spatial correlation coefficients are similar but somewhat weaker than winter, with positive values over the British Isles, Scandinavia and north Africa. 
Table 2. Winter and summer months with the associated normalized PC1 used for calculating the ensemble average for positive and negative NAO phase.

\begin{tabular}{|c|c|c|c|c|c|c|c|c|}
\hline \multicolumn{4}{|c|}{ Winter (DJF) } & \multicolumn{5}{|c|}{ Summer (JJA) } \\
\hline \multicolumn{2}{|l|}{ NAO- } & \multicolumn{2}{|c|}{ NAO+ } & \multicolumn{3}{|c|}{ NAO- } & \multicolumn{2}{|c|}{ NAO+ } \\
\hline month year & index & month year & index & month & h year & index & month year & index \\
\hline Jan 1980 & -1.6 & Dec 1982 & +1.0 & Jul & 1980 & -1.4 & Jul 1982 & +1.0 \\
\hline Dec 1981 & -1.4 & Jan 1983 & +1.3 & Jun & 1982 & -2.0 & Jun 1983 & +1.6 \\
\hline Jan 1982 & -1.2 & Dec 1988 & +1.0 & Aug & 1985 & -1.1 & Aug 1983 & +1.3 \\
\hline Jan 1985 & -2.0 & Jan 1989 & +1.3 & Aug & 1986 & -1.1 & Jun 1986 & +1.4 \\
\hline Feb 1985 & -1.6 & Feb 1989 & +1.8 & Jun & 1987 & -1.8 & Jun 1988 & +1.5 \\
\hline Dec 1985 & -1.2 & Feb 1990 & +2.3 & Aug & 1987 & -1.8 & Jun 1989 & +1.1 \\
\hline Feb 1986 & -2.3 & Dec 1991 & +1.1 & Jun & 1993 & -1.1 & Jul 1989 & +1.8 \\
\hline Jan 1987 & -1.1 & Jan 1993 & +2.2 & Jul & 1993 & -2.0 & Aug 1991 & +2.0 \\
\hline Feb 1987 & -1.3 & Feb 1995 & +1.3 & Jun & 1997 & -1.5 & Jun 1994 & +2.4 \\
\hline Dec 1995 & -1.4 & Feb 1997 & +1.5 & Jun & 1998 & -2.1 & Jul 1994 & +1.3 \\
\hline Jan 1996 & -1.6 & Feb 2000 & +1.2 & Aug & 1999 & -1.0 & Aug 1994 & +1.4 \\
\hline Jan 1998 & -1.1 & Dec 2004 & +1.6 & Aug & 2004 & -1.1 & Jul 1996 & +1.6 \\
\hline Dec 2000 & -1.0 & & & & & & Jun 1999 & +2.0 \\
\hline Dec 2001 & -1.1 & & & & & & & \\
\hline Dec 2002 & -1.1 & & & & & & & \\
\hline
\end{tabular}

The NAOI/O 3 correlation pattern also shows significant values over British Isles, part of Scandinavia, but the overall pattern starts becoming different compared to the $\mathrm{PC} 1 / \mathrm{O}_{3}$ correlation pattern. The weakening of the relationship between $\mathrm{NAO}$ and $\mathrm{O}_{3}$ concentrations is in agreement with the data that show a reduced number of ground stations significantly correlated with the NAO (Fig. 4). Over central-eastern Europe the measurements and the model show correlations of opposite signs between $\mathrm{NAO}$ and $\mathrm{O}_{3}$ concentrations, but in both cases the correlations are not significant.

\section{Summer}

During summer (JJA) the highest values of surface $\mathrm{O}_{3}$ over central and southern Europe are simulated (Fig. 2) due to the interaction of atmospheric dynamics and photochemistry. The $\mathrm{PC} 1 / \mathrm{O}_{3}$ and $\mathrm{NAOI} / \mathrm{O}_{3}$ correlation patterns are remarkably different. The NAOI/O ${ }_{3}$ correlations are only significantly positive over the Baltic region and in the southern tip of Spain. Negative correlations are shown over the British Isles in agreement with the measurements. The $\mathrm{PC} 1 / \mathrm{O}_{3}$ correlation pattern shows instead a broad area of significant positive correlation that extends from western Africa up to the southern part of the British Isles. Significant negative correlations are displayed over the Adriatic sea. This different correlation behavior can also be inferred by the measurements in agreement with the simulated correlation patterns (cf. Figs. 4 and 5).

The significantly positive $\mathrm{PC} 1 / \mathrm{O}_{3}$ correlations are due to the expansion of the Azores high during positive phases of the NAO, encompassing the Iberian Peninsula up to the British Isles (Figs. 1 and 6). The extension of the Azores anticyclone carries along its eastern flank continental air masses from western and central Europe, that are rich in $\mathrm{O}_{3}$ precursors (Louka et al., 2003; Huntrieser and Schlager, 2004; Kulkarni et al., 2011), to the Iberian Peninsula and Maghreb (northwestern Africa). The surface $\mathrm{O}_{3}$ production in these areas is therefore enhanced also due to the ideal conditions of the Azores anticyclone associated with clear sky and high values of insolation. These more stable weather conditions account for the positive surface $\mathrm{O}_{3}$ anomalies of up to 8 ppbv over France, the British Isles, the North Sea and the Baltic region (Fig. 6). The negative anomalies over Adriatic Sea (Figs. 5 and 6) simulated by the model during positive NAO phases, are associated with more unstable weather with enhanced precipitation (not shown) and reduced solar insolation over this area, and consequently reduced photochemical $\mathrm{O}_{3}$ production.

The negative NAO phase leads to surface $\mathrm{O}_{3}$ negative anomalies that are shifted south compared to positive anomalies, affecting western Africa, part of the Sahara desert and a great portion of the Mediterranean Sea, whereas mainly no anomalies are displayed in the North Sea and Baltic Region (Fig. 6). The decreased $\mathrm{O}_{3}$ concentrations over south-western Europe are caused by $\mathrm{O}_{3}$ depleted European continental flow induced by the negative NAO phase, together with increased cloudiness especially in the northernmost part of this region. The prevailing westerly air-mass flow associated with the negative $\mathrm{NAO}$ brings depleted $\mathrm{O}_{3}$ air (Fig. 2) from the African continent towards the western and central Mediterranean Sea, causing over 10 ppbv negative $\mathrm{O}_{3}$ anomalies. 

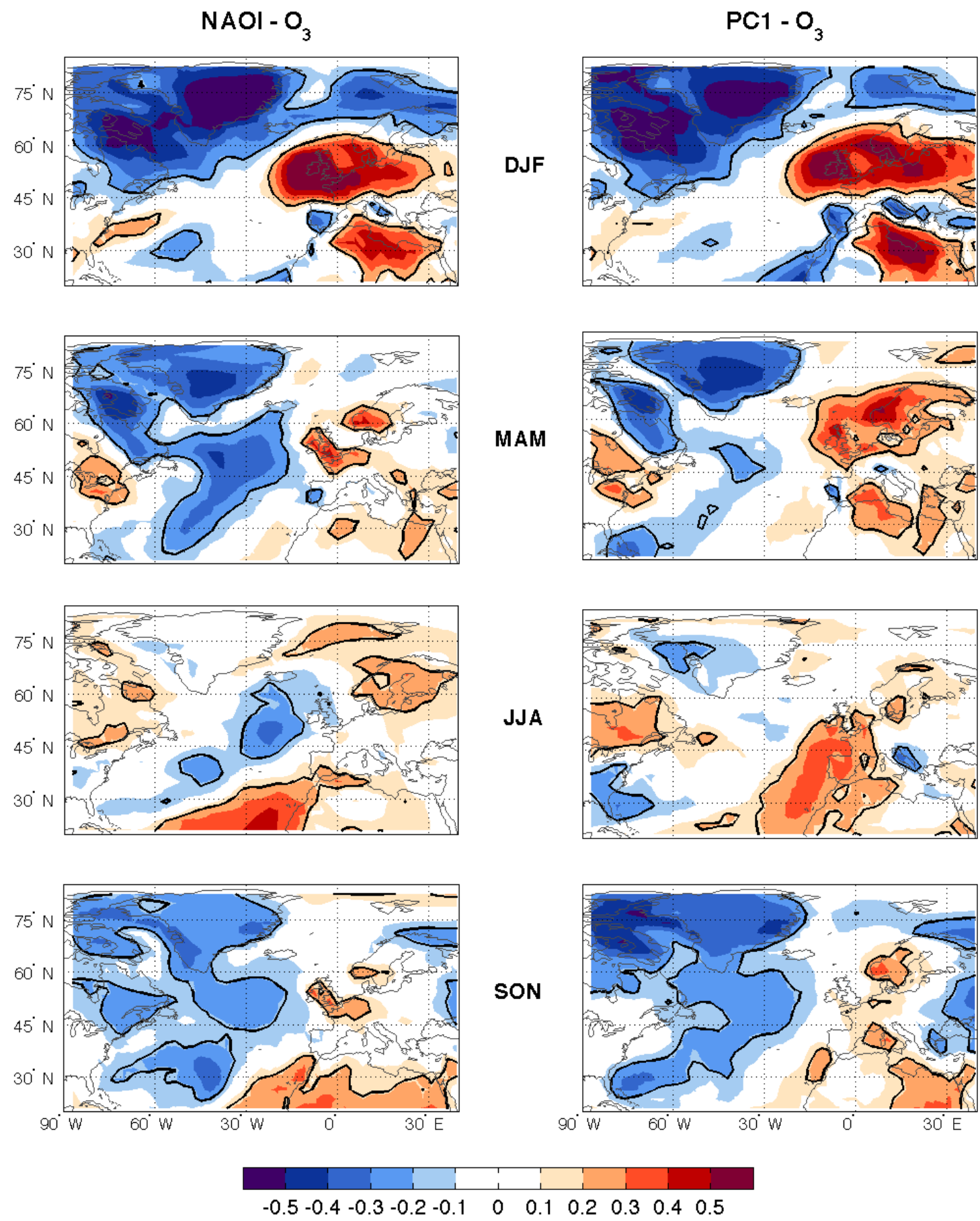

Fig. 5. Correlation between NAOI (left) and PC1 (right), and surface $\mathrm{O}_{3}$ volume mixing ratios for each season. The contours indicate where the correlation is significant at $90 \%$ confidence level.

\section{Fall}

In fall ( $\mathrm{SON}$ ), both the $\mathrm{PC} 1 / \mathrm{O}_{3}$ and $\mathrm{NAOI} / \mathrm{O}_{3}$ correlations are mostly non-significant over Europe, except in the southern tip of Scandinavia and over part of the British Isles, in broad agreement with the measurements. In fall, the NAO accounts for a smaller portion of the total variance of the atmospheric variability (Fig. 1) relative to the other seasons and therefore the link between atmospheric dynamics and $\mathrm{O}_{3}$ concentrations is at its weakest.

Our analysis shows that the $\mathrm{NAOI} / \mathrm{O}_{3}$ and the $\mathrm{PC} 1 / \mathrm{O}_{3}$ correlation patterns are similar in winter, whereas they differ in 
DJF
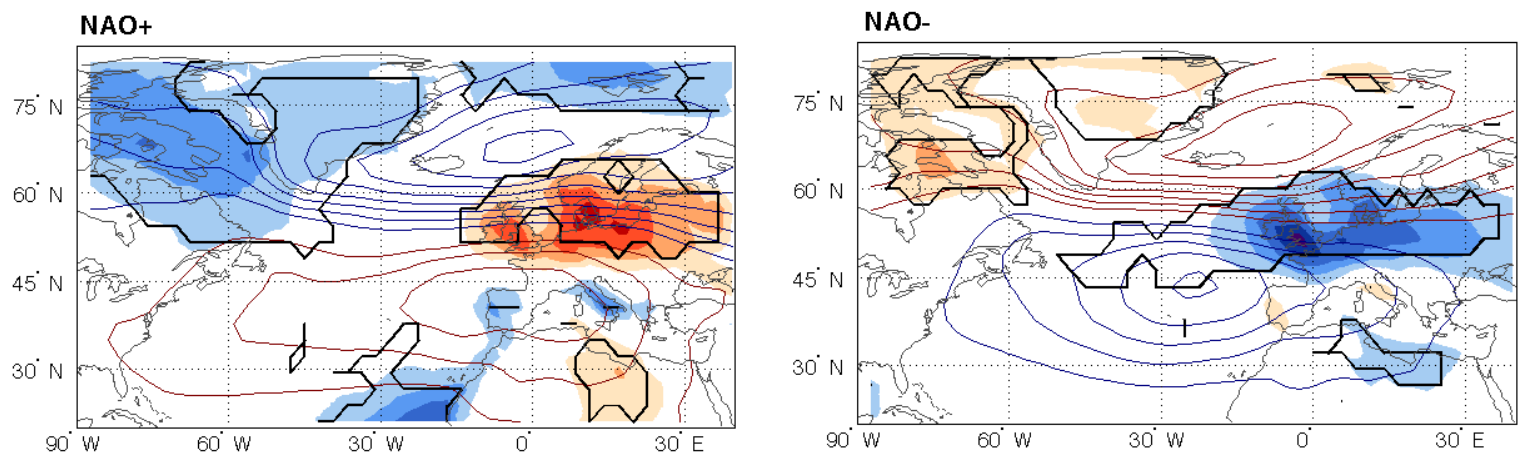

JJA
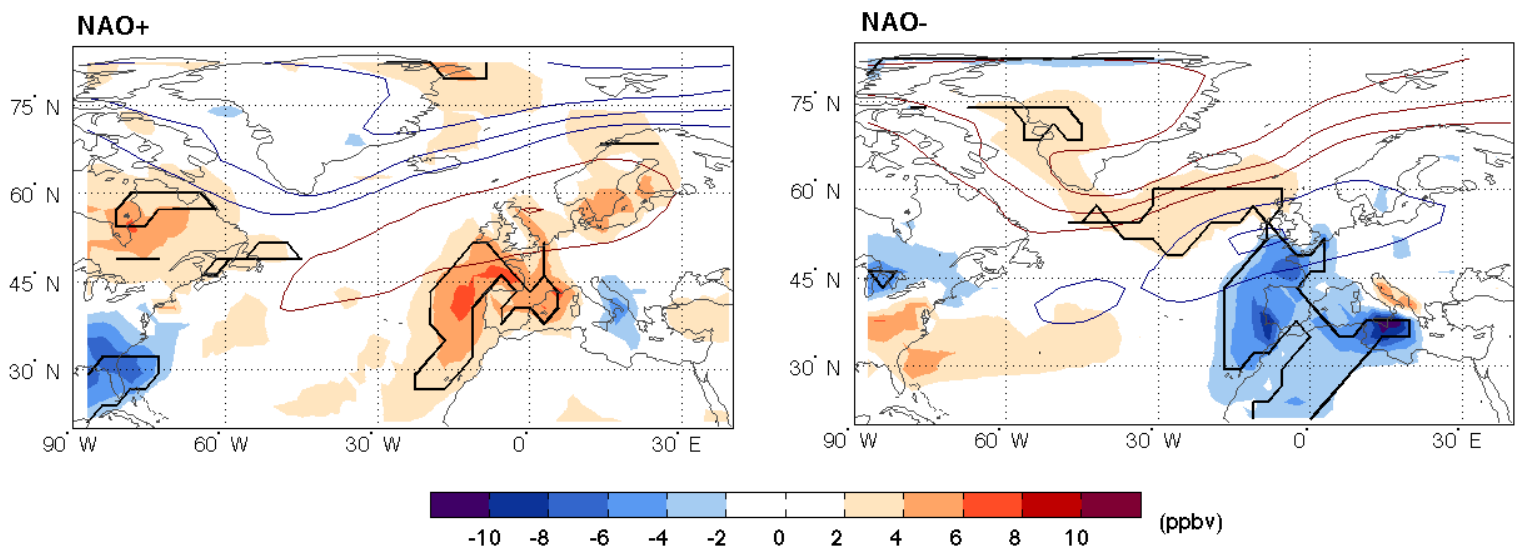

Fig. 6. Positive (red contours) and negative (blue contours) SLP and surface $\mathrm{O}_{3}$ mixing ratio (color shading) anomalies associated with the ensemble average of positive (right) and negative (left) NAO phase for winter (top) and summer (bottom) months. Contours have $1.5 \mathrm{hPa}$ interval. The bold black contours indicates $\mathrm{O}_{3}$ anomalies significant with $90 \%$ confidence.

all other seasons, especially in summer, as was previously shown by the measurements (cf. JJA correlation patterns in Figs. 4 and 5). Moreover, the areas with significant NAOI/O $\mathrm{O}_{3}$ correlation are remarkably smaller than the areas with significant $\mathrm{PC} 1 / \mathrm{O}_{3}$ correlation. This strengthens the concept that the NAOI timeseries are not accurately capturing the seasonal shift of the atmospheric circulation.

\subsection{NAO and $\mathrm{O}_{3}$ column}

Besides the long range transport of tropospheric air, the NAO may also influence transport of enriched air masses from the stratosphere into the troposphere, which may contribute to surface $\mathrm{O}_{3}$ anomalies especially in winter and early spring.

Therefore, in this section we analyze $\mathrm{O}_{3}$ anomalies throughout the depth of the troposphere associated with the ensemble averages of high and low NAO phase winter and summer months shown in Table 2.

In winter, during pronunced $\mathrm{NAO}$ phases strong $\mathrm{O}_{3}$ anomalies are displayed in the high-troposphere/lowerstratosphere that extend all the way down to the surface in central and northern Europe, and British Isles (Fig. 7). However, some of the mid-to-low latitude $\mathrm{O}_{3}$ anomalies seem instead more confined to the boundary layer, such as the anomalies over the Iberian Peninsula and Maghreb (Fig. 7, middle and bottom panels).

In summer, the tropospheric column anomalies appear to be less pronounced and restricted to the high latitudes; nevertheless, some anomalies still extends from the high latitude lower stratosphere to the mid latitude troposphere (Fig. 8).

Deep STTs reaching the surface are rare (Stohl et al., 2003), however, Figs. 7 and 8 shows that in some areas $\mathrm{O}_{3}$ anomalies extend all the way from the lower stratosphere/upper troposphere to the lower troposphere and may well be linked to changes in the number of STT events associated with the NAO phases. Unfortunately, since in our study we do not include a diagnostic for transport of stratospheric air into the troposphere, we could not quantify either the amount of surface $\mathrm{O}_{3}$ variability associated with the STT, nor the frequency of STT events associated with the NAO phases. To provide some mechanistic evidence for the role of STT on $\mathrm{O}_{3}$, we have analyzed - similarly to $\mathrm{O}_{3}-\mathrm{CO}$ mixing ratio anomalies through the depth of the troposphere associated with the NAO phases. $\mathrm{CO}$ mixing ratio can be used as a diagnostic tool for STT events (e.g. Fischer et al., 2000): 

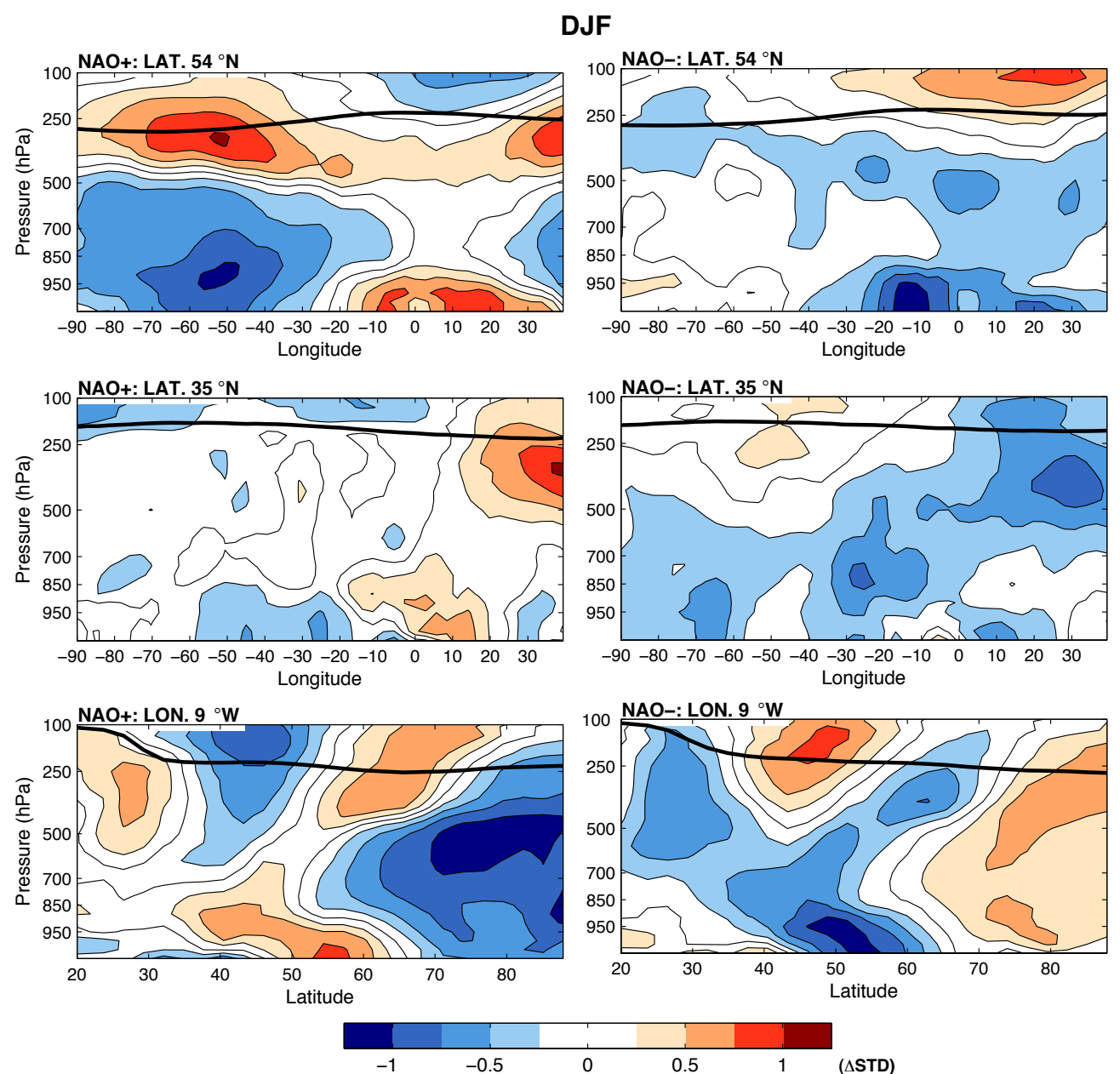

Fig. 7. Transect of normalized $\mathrm{O}_{3}$ mixing ratio anomalies for a given latitude (upper and middle panels) and longitude (lower panels) as a function of pressure in winter (DJF). $\mathrm{O}_{3}$ mixing ratio anomalies are normalized by $\mathrm{O}_{3}$ standard deviation. Thick solid line indicates the tropopause height.

negative $\mathrm{CO}$ anomalies associated with positive $\mathrm{O}_{3}$ anomalies can be used as an indicator of stratospheric origin of the air masses. In winter, during positive NAO phases and especially at mid-to-high latitudes the $\mathrm{CO}$ and $\mathrm{O}_{3}$ patterns are remarkably similar, but with a reversed sign (cf. Figs. 7 and 9). During negative NAO phases the resemblance of patterns is weaker, possibly due to the fact that intense STT events are associated to tropospheric folds in the vicinity of cutoff lows and jet positions, which are, respectively, less frequent and less strong during negative NAO phases relative to the positive one (e.g. Thompson et al., 2002). In summer, the $\mathrm{CO}$ and $\mathrm{O}_{3}$ anomalies patterns are different, suggesting a negligible influence of stratospheric $\mathrm{O}_{3}$ over lower tropospheric $\mathrm{O}_{3}$. This is in agreement with less deep and intense STT events observed in summer compared to winter (Holton et al., 1995). Our analysis suggests that STT may well affect surface $\mathrm{O}_{3}$ concentration especially during positive phase of the NAO and at mid-to-high latitudes.
The $\mathrm{O}_{3}$ anomalies that extend from the lower stratosphere to the surface seem to be due to the interplay between two main processes: (i) low level $\mathrm{O}_{3}$ transport both in winter and summer and enhanced photochemistry in summer; and (ii) STT events that are able to affect $\mathrm{O}_{3}$ concentration at the surface especially in the winter months and at mid-to-high latitudes (Figs. 9 and 10).

Lamarque and Hess (2004) and Hess and Lamarque (2007), focusing mainly on spring months, have shown that STT events have a contribution to the $\mathrm{O}_{3}$ tropospheric anomaly pattern, dominating the ozone variability signal throughout the depth of the troposphere over northern Canada and the Arctic region. On the other hand, they have shown tropospheric production of ozone and tropospheric ozone transport are also very important for the lower tropospheric ozone over the Atlantic basin and Europe. Therefore, STT events do play a role in the overall surface baseline ozone budget (see also Hocking et al., 2007). Hence, when a given NAO phase persists for several subsequent years, STTs 

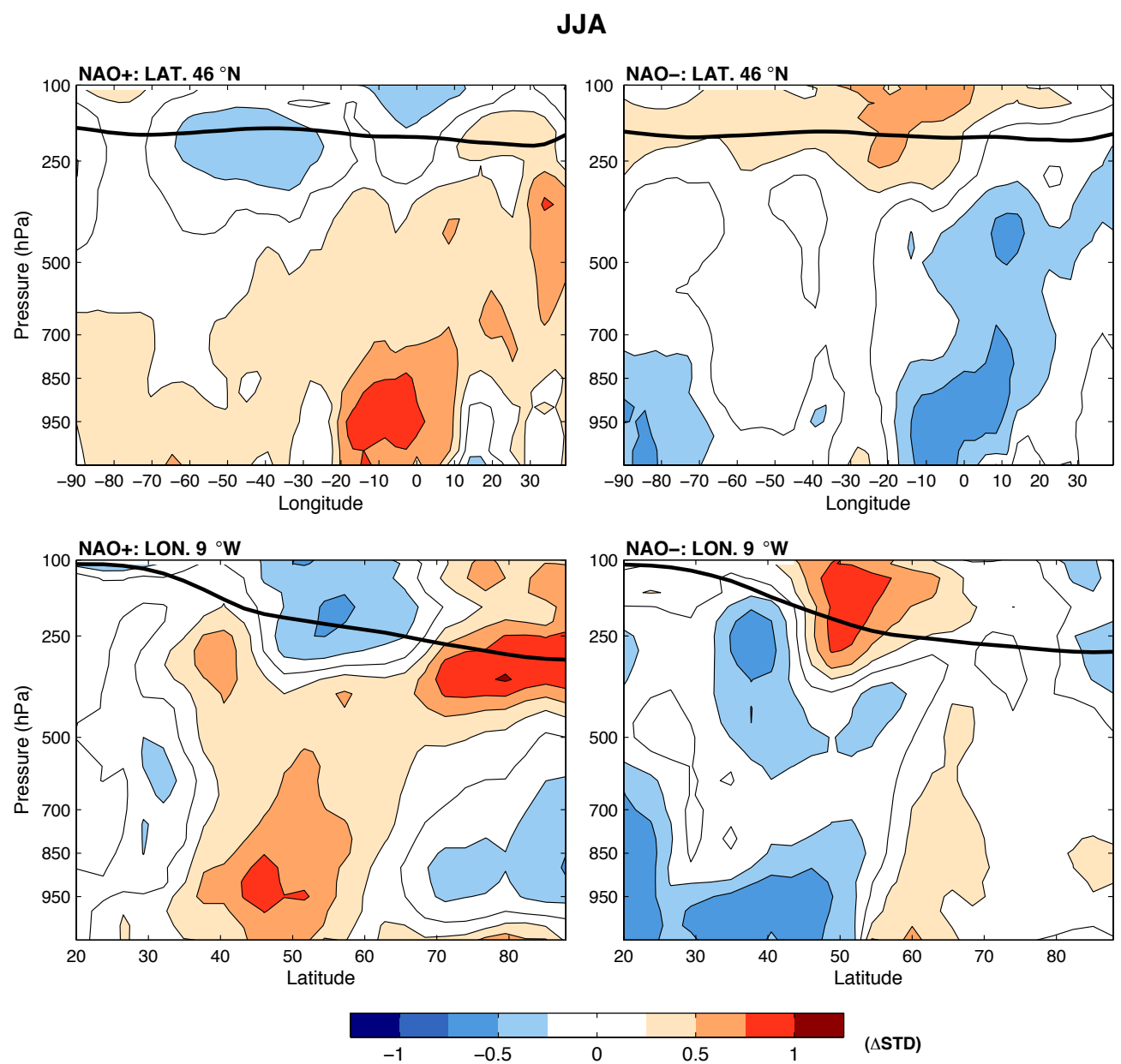

Fig. 8. Transect of normalized $\mathrm{O}_{3}$ mixing ratio anomalies for a given latitude (upper panels) and longitude (lower panels) as a function of pressure in summer (JJA). $\mathrm{O}_{3}$ mixing ratio anomalies are normalized by $\mathrm{O}_{3}$ standard deviation. Thick solid line indicates the tropopause height.

may also contribute to long term trends in surface $\mathrm{O}_{3}$ concentrations.

\section{Discussion}

We have described the relationship existing between atmospheric dynamics and $\mathrm{O}_{3}$ variability throughout the year using both measurements from ground stations spread over Europe and a coupled atmosphere-chemistry model.

Our study shows that the NAO has a sizeable impact on $\mathrm{O}_{3}$ concentrations in many areas of Europe in all seasons, except in fall. However, while the standard method of characterizing the NAO, i.e. the station-based NAO index, captures the atmosphere circulation $/ \mathrm{O}_{3}$ concentrations relationship in winter and spring, it fails in summer. On the other hand, we show that the Empirical Orthogonal Function-based index (i.e. the PC1) is able to detect the $\mathrm{NAO} / \mathrm{O}_{3}$ relationship not only in winter and spring but also in summer. This behavior is due to the fact the EOF analysis takes into account the seasonal shifting of the NAO centers of action throughout the year, in contrast to the station-based NAOI which is fixed in space. Our study shows that the NAOI is a useful metric when addressing correlations with winter/early spring atmospheric circulation, because it provides similar or better results (Figs. 4 and 5) and it is an easier analysis tool compared to the EOF analysis. For the summer months, instead, the $\mathrm{PC} 1 / \mathrm{O}_{3}$ correlations show superior results and the $\mathrm{PC} 1$ timeseries should be used rather than the NAOI (see for example Fig. 5): the two stations used to calculate the NAOI are not representative of the summer atmospheric circulation anymore since the NAO centers of action in this season are shifted northwards compared to winter (Fig. 1). Therefore, an interpretation of the $\mathrm{NAOI} / \mathrm{O}_{3}$ correlation pattern in seasons other than winter may be difficult and lead to erroneous conclusions that in some areas or seasons there is no relationship between the $\mathrm{NAO}$ and surface $\mathrm{O}_{3}$ concentrations. In order to evaluate the possibility of accounting for the summer northward shift of atmospheric circulation, simply using two alternative locations rather than the canonical ones (northern 


\section{DJF}
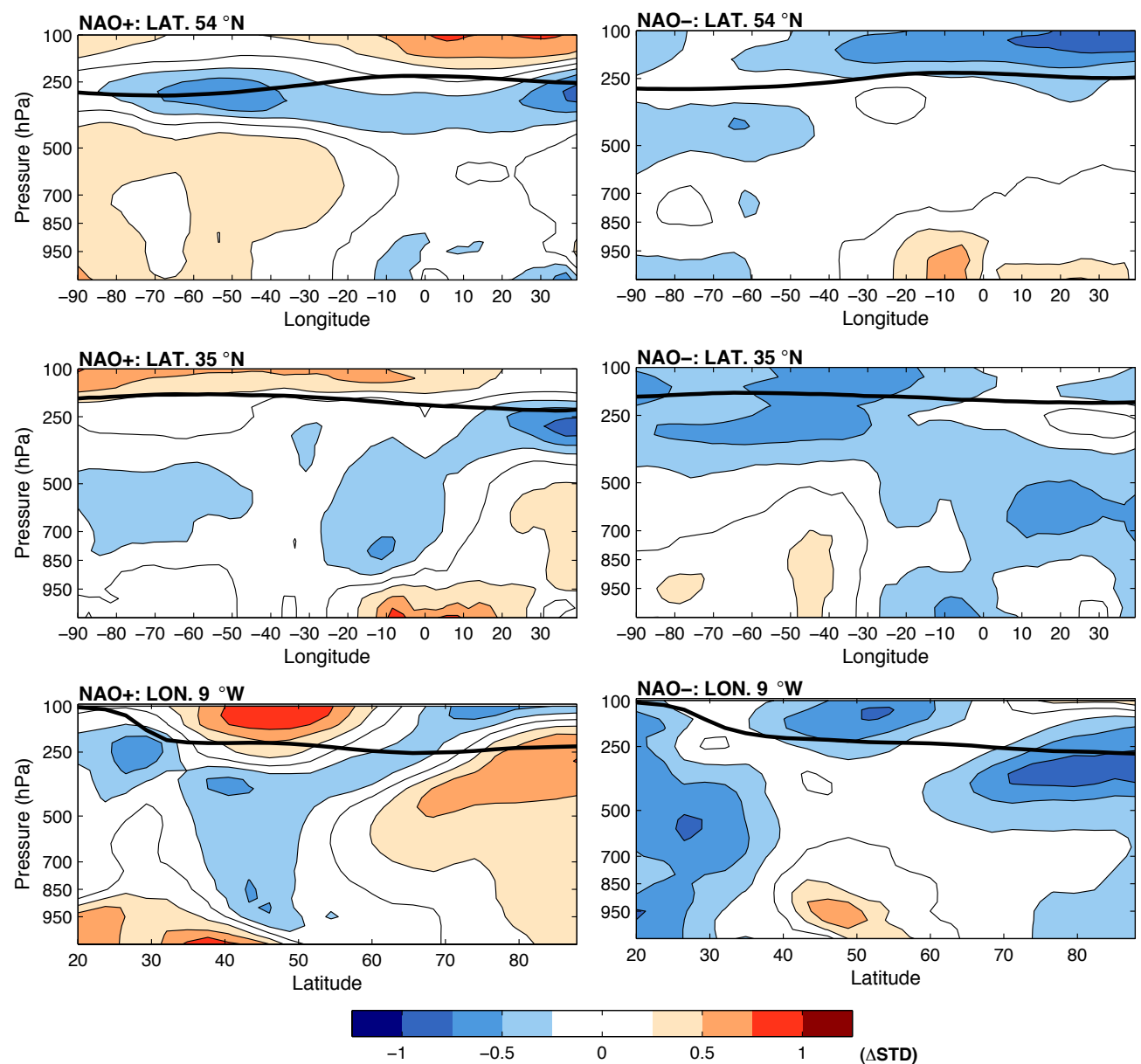

Fig. 9. Transect of normalized CO mixing ratio anomalies for a given latitude (upper and middle panels) and longitude (lower panels) as a function of pressure in winter. $\mathrm{CO}$ mixing ratio anomalies are normalized by $\mathrm{CO}$ standard deviation. Thick solid line indicates the tropopause height.

location: $65^{\circ} \mathrm{N}, 23^{\circ} \mathrm{W}$ and southern location: $38^{\circ} \mathrm{N}, 26^{\circ} \mathrm{W}$ ) or the EOF analysis, we have looked for the two model grid boxes that maximizes the correlation between the new summer-NAOI (SNAOI) and the PC1. We have found that the northern location shifts at $82^{\circ} \mathrm{N}, 8^{\circ} \mathrm{W}$ and the southern center of action at $43^{\circ} \mathrm{N}, 25^{\circ} \mathrm{W}$. The SNAOI calculated using the above-mentioned centers of action has a correlation of 0.85 with the summer PC1 (instead of 0.59 of the standard locations). However, while the SNAOI is able to capture ozone positive anomalies over the Iberian Peninsula, it fails in capturing the correlation over the British Isles (cf. Figs. 11 and 5). Therefore, the PC1 timeseries remains the best atmospheric predictor for surface ozone concentrations in summer over Europe as a whole.

Correlations between NAO and surface $\mathrm{O}_{3}$ concentrations are interesting from a general standpoint, but they are also relevant for air quality management during summer. The NAO has a lingering forecasting skill at intraseasonal (3 to 6 weeks) time scale (Johansson, 2007) and the corresponding
$\mathrm{PC} 1$ values can be used to identify areas at risk of high $\mathrm{O}_{3}$ concentrations, supporting chemical weather forecasting on a monthly timescale.

On interannual to decadal timescales the PC1 timeseries tendency may be used to understand observed $\mathrm{O}_{3}$ background trends and variability: if a specific NAO phase persists for several years the induced $\mathrm{O}_{3}$ anomalies (Fig. 6) may effect the background climatological surface $\mathrm{O}_{3}$.

Surface $\mathrm{O}_{3}$ measurements have shown an upward trend in central and northern Europe (Monk, 2003; Simmonds et al., 2004; Jonson et al., 2006; Cui et al., 2011; Wilson et al., 2012) especially in winter months in the 1990s in good agreement with modeled $\mathrm{O}_{3}$ concentrations (see Fig. 11 and Pozzoli et al., 2011). Pozzoli et al. (2011) have also shown an increase in modeled surface $\mathrm{O}_{3}$ concentrations over Europe during the period 1980-2005 even when the anthropogenic emissions of $\mathrm{O}_{3}$ precursors were kept at constant levels. They attributed the surface $\mathrm{O}_{3}$ concentration increase to changes in natural emissions and meteorology without providing further 


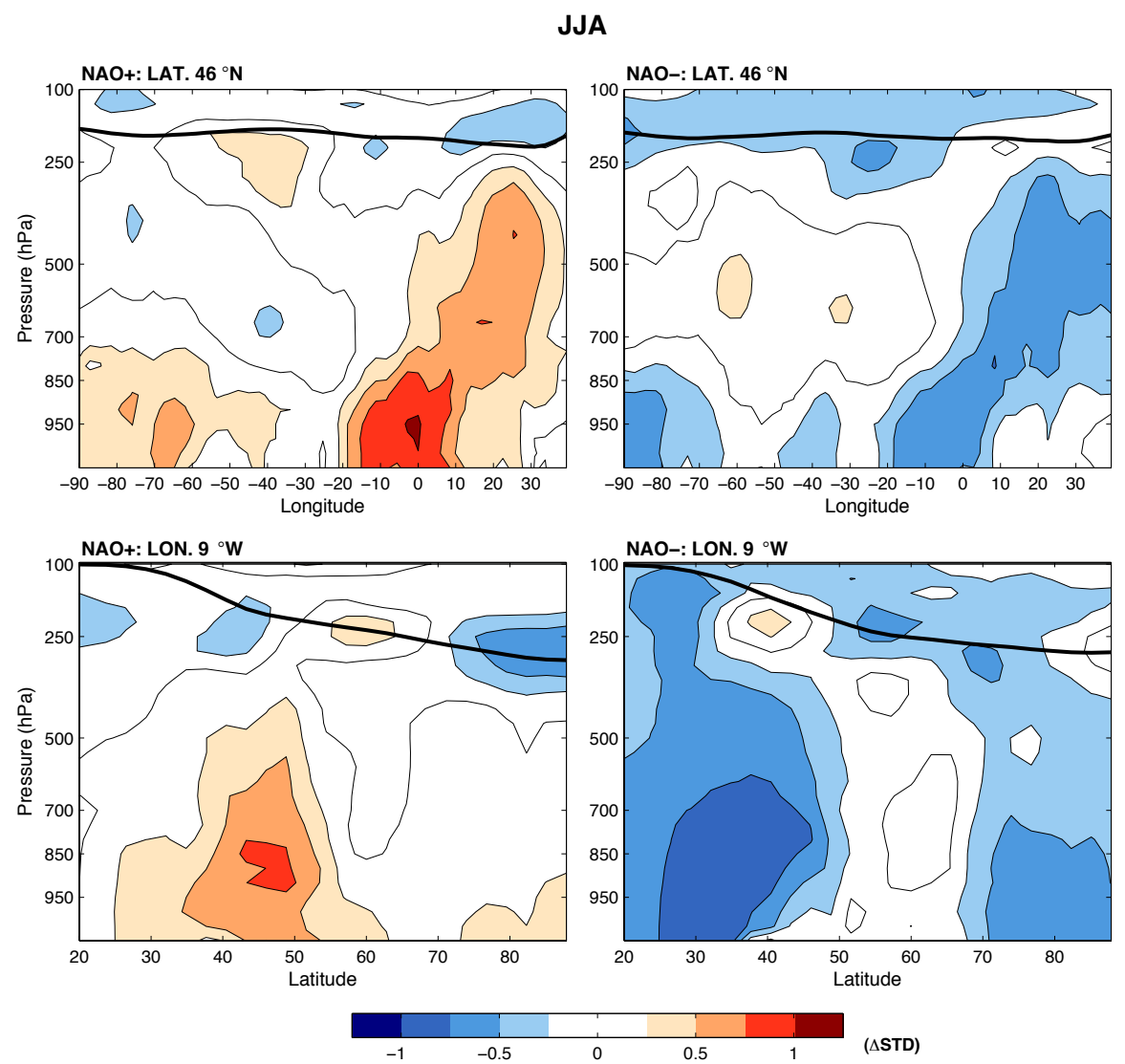

Fig. 10. Transect of normalized CO mixing ratio anomalies for a given latitude (upper panels) and longitude (lower panels) as a function of pressure in summer. CO mixing ratio anomalies are normalized by $\mathrm{CO}$ standard deviation. Thick solid line indicates the tropopause height.

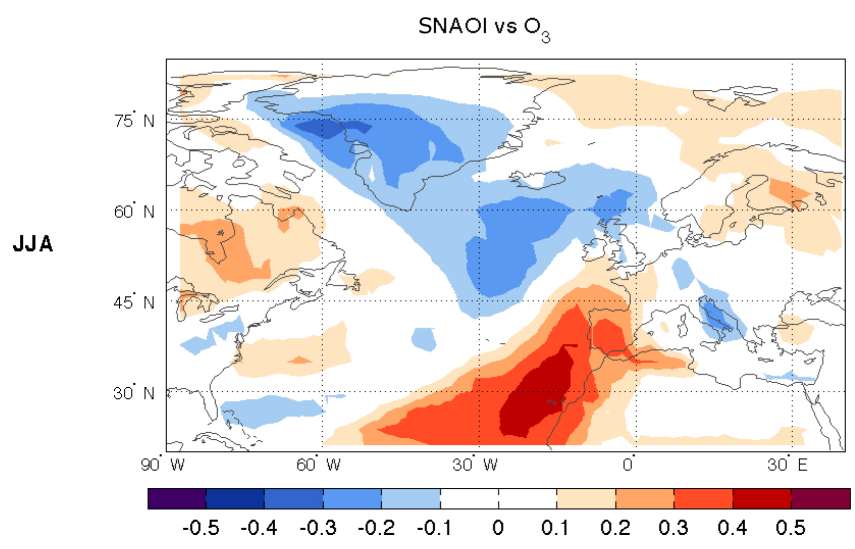

Fig. 11. Correlation between SNAOI - calculated using the new locations - and surface $\mathrm{O}_{3}$ mixing ratios in summer (JJA).

analysis of the underlying mechanisms. As seen in Sect. 3.1, the NAO had a persisting positive phase from the late 1980s until the end of the 1990s in three out of four seasons and we show that the NAO positive phase leads to positive surface $\mathrm{O}_{3}$ anomalies of up to 8 ppbv on average in a great part of western and northern Europe. Wilson et al. (2012) have demonstrated how individual years have a significant impact on ozone trends when calculated over short timescale $(10$ $15 \mathrm{yrs})$. Therefore, the NAO behavior and the associated surface $\mathrm{O}_{3}$ anomalies may explain the trends reported over western and northern Europe (e.g. Carslaw, 2005; Wilson et al., 2012). For example, the $\mathrm{O}_{3}$ trend at Mace Head is more pronounced in winter and early spring seasons when the STT is also at the maximum (Holton et al., 1995): Figs. 7 and 8 show how positive NAO phases lead to $\mathrm{O}_{3}$ anomalies that extend from the lower stratosphere/upper troposphere to the surface; this could indicate increased STT events over northern and western Europe during the positive NAO phases as also shown by Sprenger and Wernli (2003) - that together with low level $\mathrm{O}_{3}$ transport may eventually affect the overall surface $\mathrm{O}_{3}$ budget.

Finally, the trend in surface $\mathrm{O}_{3}$ at Mace Head has flattened since 2000 (Fig. 12) following the NAO tendency towards less positive NAO phases (http://www.cgd.ucar.edu/ cas/jhurrell/indices.info.html\#naostatann). This further corroborates the potential influence of the NAO on surface $\mathrm{O}_{3}$ budgets in western and northern Europe.

An important implication is that under climate change conditions, with increasing greenhouse gas concentrations 

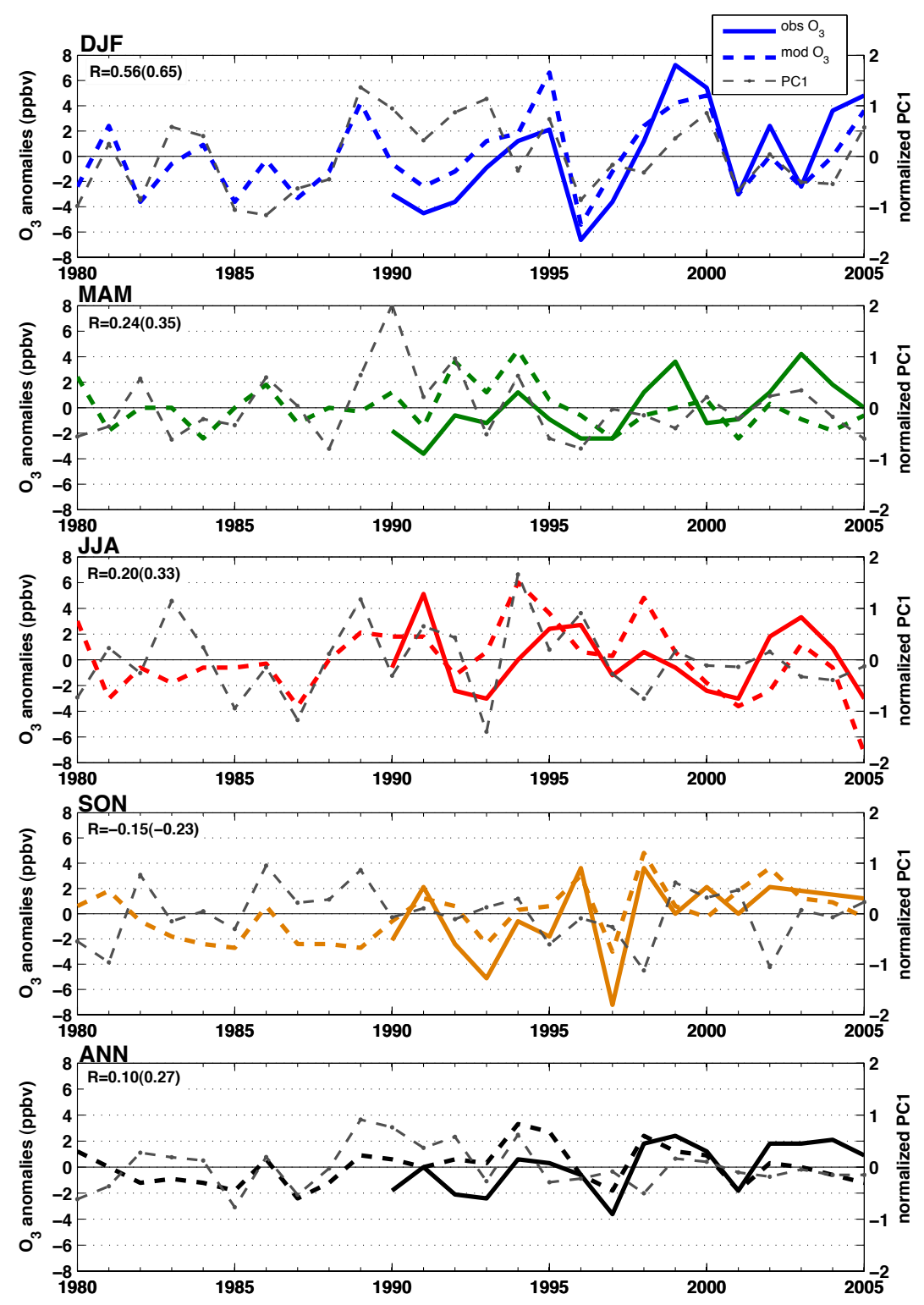

Fig. 12. Modelled (dashed lines) and observed (solid lines) surface $\mathrm{O}_{3}$ mixing ratio trends at Mace Head for each season and the annual mean. The gray dashed line displays the normalized seasonally averaged PC1 timeseries. Bold numbers in the upper left corners show the correlation between PC1 and observed and modeled (in brackets) $\mathrm{O}_{3}$ mixing ratios. The correlations are significant at $90 \%$ confidence level when higher than 0.41 for observed $\mathrm{O}_{3} / \mathrm{PC} 1$ correlation and 0.32 for modeled $\mathrm{O}_{3} / \mathrm{PC} 1$ correlation.

in the next decades, several climate model simulations (e.g. Kuzmina et al., 2005; Stephenson et al., 2006) predict a positive wintertime NAO trend. Recently Bladé et al. (2011) have shown that future summer NAO may also prefer the positive state, extending the observed positive trend started in 1967 (see Fig. 1 in Hurrell and Folland, 2002). While the wintertime NAO trends may be fundamental for understanding the overall $\mathrm{O}_{3}$ concentrations, the summertime NAO trends are extremely important for ozone air quality over centralwestern and southwestern Europe, and potentially eastern US and Canada as well (Figs. 5 and 6). The positive summer
NAO trend between the 70s and 90s has caused a change toward persistent anticyclonic flow (Hurrell and Folland, 2002) and it corresponded to an increase in mean temperatures in central England. Greatbach and Rong (2006) found that a strong correlation between summer NAO and central England temperature holds for much of the twentieth century. The increased summer NAOI also led to a lowering of precipitation over much of northern Europe. As seen in Sect. 3.1, this meteorological pattern favors positive surface $\mathrm{O}_{3}$ anomalies from the Iberian peninsula up to the British Isles and Baltic region (Fig. 6). If the positive trend in summer NAO 
persists, these areas will likely be more frequently exposed to higher-than-normal $\mathrm{O}_{3}$ concentrations with consequences for $\mathrm{O}_{3}$ abatement strategies.

Our study highlights the importance of the NAO in driving surface ozone variability in large parts of Europe, not only affecting low level transport but also middle and upper troposphere and stratosphere-to-troposphere transport. However, a quantitative analysis on the relative impact of STTs and low level transport associated to the NAO phases on surface ozone concentrations was not possible using our chemical re-analysis model simulation, due to a lack of appropriate diagnostic tools. Therefore, we strongly recommend that future studies using climate-chemistry models are supplemented with appropriate diagnostics (e.g. tracers) to investigate more in depth the effects of each NAO phase on surface ozone interannual and decadal variability and trend, as done for example by Hess and Lamarque (2007). However, new studies should not just focus on spring, but also in other seasons.

\section{Conclusions}

In this study, we analyze how the atmospheric general circulation influences ozone concentrations in Europe at the surface and throughout the depth of the troposphere and lower stratosphere, using ground station measurements and a coupled atmosphere-chemistry model for the period 1980 2005. The main findings are:

1. The North Atlantic Oscillation (NAO) influences surface ozone concentrations over Europe in all seasons except in fall, when significant positive correlation between the NAO and surface ozone are detected only in part of the British Isles and southern Scandinavia.

2. The standard NAO Index (NAOI) is a good atmospheric circulation predictor for surface ozone concentrations in winter over Europe, whereas it fails in summer; therefore, it is a simple and attractive metric to analyze variability of atmospheric trace gases connected with winter and early spring atmospheric circulation.

3. The PC1 timeseries associated with the Empirical Orthogonal Function analysis of the sea level pressure field, is the best atmospheric circulation predictor for surface ozone concentrations in summer over Europe and it could also be used to identify sensitive areas to forthcoming ozone pollution episodes.

4. The NAO behavior in the last decades likely had an influence on the positive trend in surface ozone concentration seen over northern and western Europe.
Acknowledgements. This work was funded by the European Community's Seventh Framework Program (FP7) in the project PEGASOS. The simulations were performed on the computers at Deutsches Klimarechenzentrum (DKRZ). We would like to thank the EMEP network for providing ozone measurements over Europe.

Edited by: M. Kanakidou

\section{References}

Akimoto, H.: Global air quality and pollution, Science, 302, 17161719, 2003.

Auvray, M., Bey, I., Llull, E., Schultz, M. G., and Rast, S.: A model investigation of tropospheric ozone chemical tendencies in long-range transported pollution plumes, J. Geophys. Res., 112, D05304, doi:10.1029/2006JD007137, 2007.

Barnston, A. G. and Livezey, R. E.: Classification, seasonality and persistence of low-frequency atmospheric circulation patterns, Mon. Weather Rev., 115, 1083-1126, 1987.

Bladé, I., Liebmann, B., Fortuny, D., and van Oldenborgh, G. J.: Observed and simulated impacts of the summer NAO in Europe: Implications for projected drying in the Mediterranean region, Clim. Dynam., online first, doi:10.1007/s00382-011-1195$\mathrm{x}, 2011$.

Bronnimann, S., Luterbacher, J., Schmutz, C., Wanner, H., and Staehelin, J.: Variability of total ozone at Arosa, Switzerland, since 1931 related to atmospheric circulation indices, Geophys. Res. Lett., 27, 2213-2216, 2000.

Bronnimann, S., Buchmann, B., and Wanner, H.: Trends in nearsurface ozone concentrations in Switzerland: the 1990s, Atmos. Environ., 36, 2841-2852, 2002.

Brown-Steiner, B. and Hess, P.: Asian influence on surface ozone in the United States: A comparison of chemistry, seasonality, and transport mechanisms, J. Geophys. Res., 116, D17309, doi:10.1029/2011JD015846, 2011.

Carslaw, D. C.: On the changing seasonal cycles and trends of ozone at Mace Head, Ireland, Atmos. Chem. Phys., 5, 34413450, doi:10.5194/acp-5-3441-2005, 2005.

Creilson, J. K., Fishman, J., and Wozniak, A. E.: Intercontinental transport of tropospheric ozone: a study of its seasonal variability across the North Atlantic utilizing tropospheric ozone residuals and its relationship to the North Atlantic Oscillation, Atmos. Chem. Phys., 3, 2053-2066, doi:10.5194/acp-3-2053-2003, 2003.

Christoudias, T., Pozzer, A., and Lelieveld, J.: Influence of the North Atlantic Oscillation on air pollution transport, Atmos. Chem. Phys., 12, 869-877, doi:10.5194/acp-12-869-2012, 2012.

Cui, J., Pandey Deolal, S., Sprenger, M., Henne, S., Staehelin,J., Steinbacher, M., and Nédélec, P.: Free tropospheric ozone changes over Europe as observed at Jungfraujoch (1990-2008): An analysis based on backward trajectories, J. Geophys. Res., 116, D10304, doi:10.1029/2010JD015154, 2011.

Dentener, F., Stevenson, D., Ellingsen, K., van Noije, T., Schultz, M., Amann, M., Atherton, C., Bell, N., Bergmann, D., Bey, I., Bouwman, L., Butler, T., Cofala, J., Collins, B., Drevet, J., Doherty, R., Eickhout, B., Eskes, H., Fiore, A., Gauss, M., Hauglustaine, D., Horowitz, L., Isaksen, I. S. A., Josse, B., Lawrence, M. Krol, M., Lamarque, J. F., Montanaro, V., Muller, J. F., Peuch, V. H., Pitari, G., Pyle, J., Rast, S., Rodriguez, J., Sanderson, M., 
Savage, N. H., Shindell, D., Strahan, S., Szopa, S., Sudo, K., Van Dingenen, R., Wild, O., and Zeng, G.: The global atmospheric environment for the next generation, Environ. Sci. Technol., 40, 3586-3594, 2006

Duncan B. N. and Bey, I.: A modeling study of the export pathways of pollution from Europe: Seasonal and interannual variations (1987-1997), J. Geophys. Res.-Atmos., 109, D08301, doi:10.1029/2003JD004079, 2004.

Eckhardt, S., Stohl, A., Beirle, S., Spichtinger, N., James, P., Forster, C., Junker, C., Wagner, T., Platt, U., and Jennings, S. G.: The North Atlantic Oscillation controls air pollution transport to the Arctic, Atmos. Chem. Phys., 3, 1769-1778, doi:10.5194/acp-31769-2003, 2003.

Ellingsen, K., Gauss, M., Van Dingenen, R., Dentener, F. J., Emberson, L., Fiore, A. M., Schultz, M. G., Stevenson, D. S., Ashmore, M. R., Atherton, C. S., Bergmann, D. J., Bey, I., Butler, T., Drevet, J., Eskes, H., Hauglustaine, D. A., Isaksen, I. S. A., Horowitz, L. W., Krol, M., Lamarque, J. F., Lawrence, M. G., van Noije, T., Pyle, J., Rast, S., Rodriguez, J., Savage, N., Strahan, S., Sudo, K., Szopa, S., and Wild, O.: Global ozone and air quality: a multi-model assessment of risks to human health and crops, Atmos. Chem. Phys. Discuss., 8, 2163-2223, doi:10.5194/acpd8-2163-2008, 2008.

Endresen, Ø., Sørgård, E., Sundet, J. K., Dalsøren, S. B., Isaksen, I. S. A., Berglen, T. F., and Gravir, G.: Emission from international sea transportation and environmental impact, J. Geophys. Res., 108, 4560, doi:10.1029/2002JD002898, 2003.

Fehsenfeld, F. C., Daum, P., Leaitch, W. R., Trainer, M., Parrish, D. D., and Hubler, G.: Transport and processing of O-3 and O3 precursors over the North Atlantic: An overview of the 1993 North Atlantic Regional Experiment (NARE) summer intensive, J. Geophys. Res.-Atmos., 101, 28877-28891, 1996.

Fischer, H., Wienhold, F. G., Hoor, P., Bujok, O., Schiller, C., Siegmund, P., Ambaum, M., Scheeren, H. A., and Lelieveld, J.: Tracer correlations in the northern high latitude lowermost stratosphere: Influence of cross-tropopause mass exchange, Geophys. Res. Lett., 27, 97-100, 2000.

Fishman, J., Wozniak, A. E., and Creilson, J. K.: Global distribution of tropospheric ozone from satellite measurements using the empirically corrected tropospheric ozone residual technique: Identification of the regional aspects of air pollution, Atmos. Chem. Phys., 3, 893-907, doi:10.5194/acp-3-893-2003, 2003.

Fyfe, J. C., Boer, G. J., and Flato, G. M.: The Arctic and Antarctic oscillations and their projected changes under global warming, Geophys. Res. Lett., 26, 1601-1604, 1999.

Gillett, N. P., Baldwin, M. P., and Allen, M. R.: Evidence for nonlinearity in observed stratospheric circulation changes, J. Geophys. Res.-Atmos., 106, 7891-7901, 2001.

Greatbatch, R. J. and Rong, P. P.: Discrepancies between different Northern Hemisphere summer atmospheric circulation data products, J. Climate, 19, 1261-1273, 2006.

Guerova, G., Bey, I., Attié, J.-L., Martin, R. V., Cui, J., and Sprenger, M.: Impact of transatlantic transport episodes on summertime ozone in Europe, Atmos. Chem. Phys., 6, 2057-2072, doi:10.5194/acp-6-2057-2006, 2006.

Hagemann, S., Arpe, K., and Roeckner, E.: Evaluation of the Hydrological Cycle in the ECHAM5 Model, J. Climate, 19, 38103827, 2006.
Hess, P. G. and Lamarque, J.-F.:Ozone source attribution and its modulation by the Arctic oscillation during the spring months, J. Geophys. Res.-Atmos., 112, D11303, doi:10.1029/2006JD007557, 2007.

Hess, P. and Mahowald, N.: Interannual variability in hindcasts of atmospheric chemistry: the role of meteorology, Atmos. Chem. Phys., 9, 5261-5280, doi:10.5194/acp-9-5261-2009, 2009.

Hocking, W. K., Carey-Smith, T., Tarasick, D., Argall, S., Strong, K., Rochon, Y., Zawadzki, I., and Taylor, P. A.: Detection of Stratospheric Ozone Intrusions by Windprofiler Radars, Nature, 450, 281-284, 2007.

Holton, J. .R., Haynes, P. H., McIntyre, M. E., Douglass, A. R., Rood, R. B,. and Pfister, L.: Stratosphere-troposphere exchange, Rev. Geophys., 33, 403-439, 1995.

Horowitz, L., Walters, S., Mauzerall, D., Emmons, L., Rasch, P., Granier, C., Tie, X., Lamarque, J., Schultz, M., Tyndall, G., Orlando, J., and Brasseur, G.: A global simulation of tropospheric ozone and related tracers: Description and evaluation of MOZART, version 2, J. Geophys. Res.-Atmos., 108, 4784, doi:10.1029/2002JD002853,

Huntrieser and Schlager: Air pollution export from and import to Europe: experimental evidence, edited by: Hutzinger, O., Air Pollution, Springer, Berlin, Germany, 69-98, 2004.

Hurrell, J. W.: Decadal trends in the North Atlantic Oscillation: regional temperatures and precipitation, Science, 269, 676-679, 1995.

Hurrell, J. W. and Folland, C. K. : A Change in the Summer Atmospheric Circulation over the North Atlantic, CLIVAR Exchanges, 25, 52-54, 2002.

Hurrell, J. W., Kushnir,Y., Ottersen, G., and Visbeck, M.: An overview of the North Atlantic Oscillation, in: The North Atlantic Oscillation: Climatic Significance and Environmental Impact, AGU monograph, 13, 1-35, 2003.

Jeuken, A., Siegmund, P., Heijboer, L., Feichter, J., and Bengtsson, L.: On the potential of assimilating meteorological analyses in a global climate model for the purpose of model validation, J. Geophys. Res., 101, 16939-16950, 1996.

Johansson, Å.: Prediction skill of the NAO and PNA from daily to seasonal time scales, J. Climate, 20, 1957-1975, 2007.

Jonson, J. E., Simpson, D., Fagerli, H., and Solberg, S.: Can we explain the trends in European ozone levels?, Atmos. Chem. Phys., 6, 51-66, doi:10.5194/acp-6-51-2006, 2006.

Kulkarni, P. S., Bortoli, D., Salgado, R., Anton, M., Costa, M. J., and Silva, A. M.: Tropospheric ozone variability over the Iberian Peninsula, Atmos. Environ., 45, 174-182, 2011.

Kuzmina, S. I., Bengtsson, L., Johannessen, O. M., Drange, H., Bobylev, L. P., and Miles, M. W.: The North Atlantic Oscillation and greenhouse-gas forcing, Geophys. Res. Lett., 32, L04703, doi:10.1029/2004GL021064, 2005.

Lamarque, J. F. and Hess, P. G.: Arctic Oscillation modulation of the Northern Hemisphere spring tropospheric ozone, Geophys. Res. Lett., 31, 2246-2269, 2004.

Lelieveld, J. and Dentener, F. J.: What controls tropospheric ozone?, J. Geophys. Res., 105, 3531-3551, 2000.

Li, Q. B., Jacob, D. J., Bey, I., Palmer, P. I., Duncan, B. N., Field, B. D., Martin, R. V., Fiore, A.M., Yantosca, R. M., Parrish, D. D., Simmonds, P. G., and Oltmans, S. J.: Transatlantic transport of pollution and its effects on surface ozone in Europe and North America, J. Geophys. Res., 107, 4166, 
doi:10.1029/2001JD001422, 2002.

Lin, M., Fiore, A. M., Horowitz, L. W., Cooper,O. R., Naik, V., Holloway, J., Johnson, B. J., Middlebrook, A. M., Oltmans, S. J., Ilana B. Pollack, I. B., Ryerson, T. B., Warner, J. X., Wiedinmyer, C., Wilson, J., and Wyman, B.: Transport of Asian ozone pollution into surface air over the western United States in spring, J. Geophys. Res., 117, D00V07, doi:10.1029/2011JD016961, 2012.

Linderholm, H. W., Folland, C. K., and Walther, A.: A multicentury perspective on the summer North Atlantic Oscillation (SNAO) and drought in the eastern Atlantic Region, J. Quaternary Sci., 24, 415-425, 2009

Logan, J.: An analysis of ozonesonde data for the troposphere: Recommendations for testing 3-D models and development of a gridded climatology for tropospheric ozone, J. Geophys. Res.Atmos., 104, 16115-16149, 1999.

Louka, P., Finzi, G., Volta, M., and Colbeck, I.: Photochemical smog in South European Cities, in: Air Quality in Cities, edited by: Moussiopoulos, N., Springer-Verlag, Berlin, Germany, 185222, 2003.

Lövblad, G., Tarrasón, L., Torseth, K., and Dutchak, S.: EMEP Assessment, part 1: European perspective, Norw. Meteorol. Inst., Oslo, 2004.

Monk, P. S.: TROTREP Synthesis and Integration Report. Report to the EU FPV Energy, Environment and Sustainable Development Program., European Union, 2003.

Parrish, D. D., Ryerson, T. B., Holloway, J. S., Frost, G. J., and Fehsenfeld, F. C.: Export of North American ozone pollution to the North Atlantic Ocean, Science, 259, 1436-1439, 1993.

Pozzoli, L., Bey, I., Rast, S., Schultz, M. G., Stier, P., and Feichter, J.: Trace gas and aerosol interactions in the fully coupled model of aerosol-chemistry-climate ECHAM5HAMMOZ: 1. Model description and insights from the spring 2001 TRACE-P experiment, J. Geophys. Res., 113, D07308, doi:10.1029/2007JD009007, 2008a.

Pozzoli, L., Bey, I., Rast, S., Schultz, M. G., Stier, P., and Feichter, J.: Trace gas and aerosol interactions in the fully coupled model of aerosol-chemistry-climate ECHAM5-HAMMOZ: 2. Impact of heterogeneous chemistry on the global aerosol distributions, J. Geophys. Res., 113, D07309, doi:10.1029/2007JD009008, 2008b.

Pozzoli, L., Janssens-Maenhout, G., Diehl, T., Bey, I., Schultz, M. G., Feichter, J., Vignati, E., and Dentener, F.: Re-analysis of tropospheric sulfate aerosol and ozone for the period 1980-2005 using the aerosol-chemistry-climate model ECHAM5-HAMMOZ, Atmos. Chem. Phys., 11, 9563-9594, doi:10.5194/acp-11-95632011, 2011.

Randel, W., Wu, F., Russell, J., Roche, A., and Waters, J.: Seasonal cycles and QBO variations in stratospheric $\mathrm{CH}_{4}$ and $\mathrm{H}_{2} \mathrm{O}$ observed in UARS HALOE data, J. Atmos. Sci., 55, 163-185, 1998.

Rast, J., Schultz, M., Aghedo, A., Bey, I., Brasseur, G., Diehl, T., Esch, M., Ganzeveld, L., Kirchner, I., Kornblueh, L., Rhodin, A., Roeckner, E., Schmidt, H., Schroede, S., Schulzweida, U., Stier, P., and van Noije, T.: Evaluation of the tropospheric chemistry general circulation model ECHAM5-MOZ and its application to the analysis of the inter-annual variability in tropospheric ozone from 1960-2000 chemical composition of the troposphere for the period 1960-2000 (RETRO), MPI-Report (Reports on Earth Sys- tem Science), in preparation, 2012.

Roeckner, E., Bauml, G., Bonaventura, L., Brokopf, R., Esch, M., Giorgetta, M., Hagemann, S., Kirchner, I., Kornblueh, L., Manzini, E., Rhodin, A., Schlese, U., Schulzweida, U., and Tompkins, A.: The atmospehric general circulation model ECHAM5: Part 1, Tech. Rep. 349, Max Planck Institute for Meteorology, Hamburg, 2003.

Roeckner, E., Brokopf, R., Esch, M., Giorgetta, M., Hagemann, S., Kornblueh, L., Manzini, E., Schlese, U., and Schulzweida, U.: Sensitivity of Simulated Climate to Horizontal and Vertical Resolution in the ECHAM5 Atmosphere Model, J. Climate, 19, 3771-3791, 2006

Schultz, M., Backman, L., Balkanski, Y., Bjoerndalsaeter, S., Brand, R., Burrows, J., Dalsoeren, S., de Vasconcelos, M., Grodtmann, B., Hauglustaine, D., Heil, A., Hoelzemann, J., Isaksen, I., Kaurola, J., Knorr, W., Ladstaetter-Weißenmayer, A., Mota, B., Oom, D., Pacyna, J., Panasiuk, D., Pereira, J., Pulles, T., Pyle, J., Rast, S., Richter, A., Savage, N., Schnadt, C., Schulz, M., Spessa, A., Staehelin, J., Sundet, J., Szopa, S., Thonicke, K., van het Bolscher, M., van Noije, T., van Velthoven, P., Vik, A., and Wittrock, F.: REanalysis of the TROpospheric chemical composition over the past 40 years (RETRO). A long-term global modeling study of tropospheric chemistry, Final Report, Tech. rep., Max Planck Institute for Meteorology, Hamburg, Germany, 2007.

Simmonds, P. G., Derwent, R. G., Manning, A. L., and Spain, G.: Significant growth in surface ozone at Mace Head, Ireland, 1987-2003, Atmos. Environ., 38, 4769-4778, 2004.

Sprenger, M. and Wernli, H.: A northern hemispheric climatology of cross-tropopause exchange for the ERA15 time period (19791993), J. Geophys. Res., 108, 8521, doi:10.1029/2002JD002636, 2003.

Stephenson, D. B., Pavan, V., Collins, M., Junge, M. M., and Quadrelli, R.: North Atlantic Oscillation response to transient greenhouse gas forcing and the impact on European winter climate: a CMIP2 multi-model assessment, Clim. Dynam., 27, 401420, 2006.

Stevenson, D., Dentener, F., Schultz, M., Ellingsen, K., van Noije, T., Wild, O., Zeng, G., Amann, M., Atherton, C., Bell, N., Bergmann, D., Bey, I., Butler, T., Cofala, J., Collins, W., Derwent, R., Doherty, R., Drevet, J., Eskes, H., Fiore, A., Gauss, M., Hauglustaine, D., Horowitz, L., Isaksen, I., Krol, M., Lamarque, J., Lawrence, M., Montanaro, V., Muller, J., Pitari, G., Prather, M., Pyle, J., Rast, S., Rodriguez, J., Sanderson, M., Savage, N., Shindell, D., Strahan, S., Sudo, K., and Szopa, S.: Multimodel ensemble simulations of present-day and near-future tropospheric ozone, J. Geophys. Res.-Atmos., 111, D08301, doi:10.1029/2005JD006338, 2006.

Stier, P., Feichter, J., Kinne, S., Kloster, S., Vignati, E., Wilson, J., Ganzeveld, L., Tegen, I., Werner, M., Balkanski, Y., Schulz, M., Boucher, O., Minikin, A., and Petzold, A.: The aerosol-climate model ECHAM5-HAM, Atmos. Chem. Phys., 5, 1125-1156, doi:10.5194/acp-5-1125-2005, 2005.

Stohl, A., Bonasoni, P., Cristofanelli, P., Collins, W., Feichter, J., Frank, A., Forster, C., Gerasopoulos, E., Gaggeler, H., James, P., Kentarchos, T., Kromp-Kolb, H., Kruger, B., Land, C., Meloen, J., Papayannis, A., Priller, A., Seibert, P., Sprenger, M., Roelofs, G. J., Scheel, H. E., Schnabel, C., Siegmund, P., Tobler, L., Trickl, T., Wernli, H., Wirth, V., Zanis, P., and Zerefos, C.: Stratosphere-troposphere exchange: A review, and what we have 
learned from STACCATO, J. Geophys. Res.-Atmos., 108, 8516, doi:10.1029/2002JD002490, 2003.

Thompson, D. W. J., Lee, S., and Baldwin, M. P.: Atmospheric processes governing the Northern Hemisphere Annular Mode / North Atlantic Oscillation. In The North Atlantic Oscillation, Climate Significance and Environmental Impact, AGU monograph, 13, 1-35, 2002.

Uppala, S. M., Kållberg, P. W., Simmons, A. J., Andrae, U., Bechtold, V. D. C., Fiorino, M., Gibson, J. K., Haseler, J., Hernandez, A., Kelly, G. A., Li, X., Onogi, K., Saarinen, S., Sokka, N., Allan, R. P., Andersson, E., Arpe, K., Balmaseda, M. A., Beljaars, A. C. M., Berg, L. V. D., Bidlot, J., Bormann, N., Caires, S., Chevallier, F., Dethof, A., Dragosavac, M., Fisher, M., Fuentes, M., Hagemann, S., Hólm, E., Hoskins, B. J., Isaksen, L., Janssen, P. A. E. M., Jenne, R., Mcnally, A. P., Mahfouf, J.-F., Morcrette, J.-J., Rayner, N. A., Saunders, R. W., Simon, P., Sterl, A., Trenberth, K. E., Untch, A., Vasiljevic, D., Viterbo, P., and Woollen, J.: The ERA-40 re-analysis, Q. J. Roy. Meteorol. Soc., 131, 2961-3012, doi:10.1256/qj.04.176, 2005.
Walker, G. T.: Correlation in seasonal variation of weather, IX: A further study of world weather, Mem. Indian Meteor. Dep., 24, 275-332, 1924.

Walker, G. T. and Bliss, E. W.: World Weather, V. Mem. R. Meteorol. Soc., 4, 53-83, 1932.

Wallace, M.: North Atlantic Oscillation/annular mode: Two paradigms - one phenomenon, Q. J. Roy. Meteorol. Soc., 126, 791-805, 2000.

Wild, O. and Akimoto, H.: Intercontinental transport of ozone and its precursors in a three-dimensional global CTM, J. Geophys. Res.-Atmos., 106, 27729-27744, 2001.

Wilson, R. C., Fleming, Z. L., Monks, P. S., Clain, G., Henne, S., Konovalov, I. B., Szopa, S., and Menut, L.: Have primary emission reduction measures reduced ozone across Europe? An analysis of European rural background ozone trends 1996-2005, Atmos. Chem. Phys., 12, 437-454, doi:10.5194/acp-12-437-2012, 2012.

Yienger, J. .J, Galanter, M., Holloway, T. A., Phadnis, M. J., Guttikunda, S. K., Carmichael, G. R., Moxim, W. J., and Levy, H.: The episodic nature of air pollution transport from Asia to North America, J. Geophys. Res.-Atmos., 105, 26931-26945, 2000. 